\title{
Formaldehyde Oxidizing Enzymes and Genetically Modified Yeast Hansenula polymorpha Cells in Monitoring and Removal of Formaldehyde
}

\author{
Vladimir Sibirny², Olha Demkiv¹, Sasi Sigawi4, ${ }^{4,5}$, Solomiya Paryzhak ${ }^{1}$, \\ Halyna Klepach ${ }^{1}$, Yaroslav Korpan ${ }^{3}$, Oleh Smutok ${ }^{1}$, \\ Marina Nisnevich ${ }^{4}$, Galina Gayda ${ }^{1}$, Yeshayahu Nitzan" \\ Czesław Puchalski² and Mykhailo Gonchar ${ }^{1,2}$ \\ ${ }^{1}$ Institute of Cell Biology NAS of Ukraine, Lviv, \\ ${ }^{2}$ University of Rzeszow, Rzeszow-Kolbuszowa, \\ 3 Institute of Molecular Biology \& Genetics NAS of Ukraine, Kyiv, \\ ${ }^{4}$ Ariel University Center of Samaria, Ariel, \\ ${ }^{5}$ Bar-Ilan University, Ramat-Gan, \\ 1,3 Ukraine \\ 2Poland \\ 4,5Israel
}

\section{Introduction}

Formaldehyde (FA), a very important commercial chemical, is one of the most toxic pollutants used in many industries. It is exploited as an adhesive material in pressed wood products, as a preservative in paints and coatings, in the production of fertilizers, paper and plywood, urea-formaldehyde resins and numerous other applications (Yocom Y.E., 1991; Otson, 1992; Khoder, 2000). It is also applied in the production of cosmetics and sugar, in well-drilling fluids, in agriculture as a preservative for grains and seed dressings, in the rubber industry in the production of latex, in leather tanning and in photographic film production. FA has been a popular constituent of embalming solutions since about 1900 (Kitchens et al., 1976; Plunkett and Barbella, 1977). Approximately 30 years following its discovery, FA was introduced into medical practice as a disinfectant and tissue hardener, used in many hospitals and laboratories to preserve tissue specimens (Walker, 1964; Cox, 1984). It has medical applications as a sterilizer and is employed as an anti-viral agent and preservative in the production of vaccines, instead of the harmful merthiolate, which can cause neurodevelopmental disorders including autism and autism spectrum disorders (Offit, 2007; Geier, 2004).

FA has a negative influence on human health, especially on the central nervous, blood and immune systems. Anatomists, technicians, medical or veterinary students and embalmers are among the people who have a great risk for FA toxicity. FA can also be found in the air 
that we breathe at home and at work, in the food we eat, and in some products that we put on our skin. A major source of FA that we breathe everyday is found in smog in the lower atmosphere. Automobile exhaust from cars without catalytic converters or those using oxygenated gasoline also contain FA (Kitchens et al., 1976; National Research Council, 1982). At home, FA is produced by cigarettes and other tobacco products, gas cookers, and open fireplaces. It is found in many products used every day around the house, such as antiseptics, cosmetics, dish-washing liquids, fabric softeners, shoe-care agents, carpet cleaners, glues, lacquers, paper, plastics, and some types of wood products (Gerberich and Seaman, 1994). Inhaled FA primarily affects the airways; the severity and extent of the physiological response depends on its concentration in the air. Acute inhalation exposure to FA causes histopathologic damage (Chang et al.,1983) and DNA-protein cross-linking in the nasal mucosa of rats and rhesus monkeys (Auerbach et al.,1977; Martin et al.,1978; Griesemer et al.,1982; Casanova et al.,1989). Recently, a new health risk factor associated with FA has been revealed. Some advanced technologies of potable water pre-treatment include the ozonation process, during which FA is generated as a result of the reaction of ozone with humus traces (Schechter and Singer, 1995). FA has been in widespread use for over a century as a preservative agent in some foods, such as some types of Italian cheeses and dried foods. It has been found as a natural chemical in fruits and vegetables, and in human flesh and biological fluids (Gerberich and Seaman, 1994). In extreme cases, some frozen fish, especially of the Gadoid species, can accumulate up to $200 \mathrm{mg}$ of FA per $\mathrm{kg}$ of wet weight due to the enzymatic degradation of a natural fish component - trimethylamine oxide (Rehbein, 1995; Pavlishko et al., 2003).

FA is classified as a mutagen and possible human carcinogen (Feron et al., 1991), one of the chemical mediators of apoptosis. FA is clearly genotoxic in vitro. It induces mutations and DNA damage in bacteria. DNA-protein cross-links, DNA single-strand breaks, chromosomal aberrations, sister chromatid exchanges and gene mutations are induced in human and rodent cells. Animal studies indicate that FA is a rat carcinogen at high levels $(\geq$ $10 \mathrm{ppm}$ ) of exposure, producing nasal tumours that are both exposure duration and concentration-dependent (Shaham J. et al., 1996.

At the same time, FA is a naturally occurring metabolite produced in very small amounts in our bodies as part of our normal, everyday metabolism of serine, glycine, methionine and choline and also by the demethylation of $N-, S$ - and $O$-methyl compounds (Heck, 1984). It is estimated that endogenous FA concentration in blood is close to $0.1 \mathrm{mM}$. FA may be detoxified principally via action of formaldehyde dehydrogenase (FdDH, EC 1.2.1.1), a specific enzyme that catalyzes the conversion of FA in the presence of reduced glutathione (GSH) and NAD ${ }^{+}$to S-formylglutathione (finally, to formic acid) and NADH (Uotila and Mannervik, 1979; Pourmotabbed and Creighton,1986). S-formylglutathione (GSCH=O) is finally hydrolyzed to free formic acid:

$$
\mathrm{CH}_{2} \mathrm{O}+\mathrm{GSH} \leftrightarrow \mathrm{GS}-\mathrm{CH}_{2} \mathrm{OH}
$$

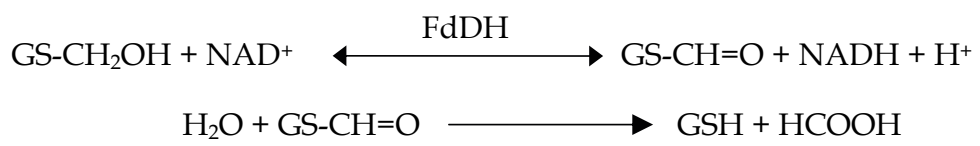

Since FdDH is a glutathione dependent enzyme, the pool of glutathione available for FA binding is important in regulating FdDH activity. Then FA can be metabolised to formate 
and enter the one carbon pool for incorporation into the cells constituents (CasanovaSchmitz, 1984). At the moment, three different FdDHes, bacterial NAD ${ }^{+}$-dependent, yeast $\mathrm{NAD}^{+}$- and GSH-dependent and bacterial dye-linked $\mathrm{NAD}^{+}$and GSH-independent, are widely used for bioanalytical purposes (Ben Ali et al., 2006, 2007; Winter and Cammann, 1989; Vastarella and Nicastri, 2005; Herschkovitz et al., 2000; Korpan et al., 1993; Gonchar et al., 2002; Korpan et al., 2010; Achmann et al., 2008; Kawamura et al., 2005).

Besides FdDH, FA can be easily oxidized by alcohol oxidase (AOX) (EC 1.1.3.13), an enzyme which is responsible in vivo for the first reaction of methanol metabolism in methylotrophic yeast (Klei van der et al, 1990). AOX is not an absolutely selective enzyme and oxidizes the hydrated form of FA to formic acid without any exogenous cofactor (Kato et al., 1976). The theoretical possibility of AOX using for FA assay is based on a known fact that FA exists in aqueous solutions in the hydrated form (95-99\% of total concentration) which has a structural resemblance to methanol and can be oxidized by AOX with the subsequent formation of formic acid and hydrogen peroxide according to the following reactions:

$$
\begin{gathered}
\mathrm{CH}_{2} \mathrm{O}+\mathrm{H}_{2} \mathrm{O} \leftrightarrow \mathrm{HOCH}_{2} \mathrm{OH} \\
\mathrm{HOCH}_{2} \mathrm{OH}+\mathrm{O}_{2} \stackrel{\mathrm{AOX}}{\longrightarrow} \mathrm{HCOOH}+\mathrm{H}_{2} \mathrm{O}_{2}
\end{gathered}
$$

\section{Methods of formaldehyde monitoring}

\subsection{Chemical and enzymatic methods}

There are many chemical methods for the determination of FA (Sibirnyi et al., 2005; Bakar et al., 2009). The traditional Nash's method (Nash, 1953) is based on the reaction of FA with acetylacetone in the presence of ammonium ions. Another widely used photometric and sufficiently sensitive analytical method exploits the reaction of FA with chromotropic acid (Sawicki et al., 1962). This approach enables the determination of the analyte in the concentration range $0.05-1.0 \mathrm{mg} \mathrm{dm}^{-3}$ (Polish Standard, 1988). Unfortunately, determination of FA involves heating the sample with chromotropic acid under strongly acidic conditions. 4-amino-3-hydrazino-5-mercapto-1,2,4-triazole (AHMT) was also proposed for FA assay (Avigad, 1983, Jung et al., 2001). FA and other aldehydes form products of different colors, which can be selectively tested spectrophotometrically. The sensitivity limit of the method is $1.5 \mathrm{nmol}$ of FA in $1 \mathrm{ml}$ sample. However, the main drawback of the AHMT method is the requirement of a very strong base.

High Performance Liquid Chromatography coupled to steam distillation and 2,4dinitrophenylhydrazine derivatization (2,4-DNPH) displayed good selectivity, precision and accuracy (Li et al., 2007).

A polarographic method has been developed for the determination of FA traces by direct in situ analyte derivatization with (carboxymethyl)trimethyl ammonium chloride hydrazide (Girard Treagent) (Chan \& Xie, 1997). The drawback of this method is the expensive apparatus required, as well as the necessity to remove oxygen traces by sparging with pure nitrogen.

A flow injection analysis (FIA) system with an incorporated gel-filtration chromatography column has been applied to determine FA using FdDH (Benchman, 1996).

\subsection{Biosensor methods}

The degree of selectivity or specificity of a given biosensor is determined by the type of biocomponent incorporated into the biosensor. Biological recognizers are divided into 3 
groups: biocatalytic, bioaffinity and hybrid receptors (Mello and Kubota, 2002). The selection of an appropriate immobilization method depends on the nature of the biological element, type of transducer used, physico-chemical properties of the analyte and operating conditions of the biosensor system (Luong et al., 1988). Biosensors can be categorized according to their transducer: potentiometric (Ion-Selective Electrodes (ISEs), Ion-Sensitive Field Effect Transistors (ISFETs)), amperometric, conductometric, impediometric, calorimetric, optical and piezoelectric.

FA selective biosensors are based on cells (Korpan et al., 1993) or enzymes used as biorecognition elements: either alcohol oxidase (AOX) (Korpan et al., 1997, 2000; Dzyadevych et al., 2001) or formaldehyde dehydrogenase (FdDH) (Herschkovitz et al., 2000; Kataky et al., 2002, Achmann et al., 2008). A number of sensor approaches for the detection of FA concentration have been published including systems operating in gas (Dennison et al., 1996; Hämmerle et al., 1996; Vianello et al., 1996) and organic phases. An optical biosensor has also been proposed for FA assay (Rindt \& Scholtissek, 1989).

Potentiometric biosensors, consisting of a $\mathrm{pH}$ sensitive field effect transistor as a transducer and either the enzyme AOX, or permeabilised yeast cells (containing AOX) as the biorecognition element, have been described by Korpan et al. (2000). These biosensors have demonstrated a high selectivity to FA with no interference response to methanol, ethanol, glucose or glycerol.

Amperometric biosensors have been suggested for the determination of FA level using FdDH (Winter \& Cammann, 1989; Hall et al., 1998). Conductometric enzymatic biosensors based on FdDH (Vianello et al., 2007) and AOX (Dzyadevych et al., 2001) have been developed for FA assay.

\section{Microbial methanol and formaldehyde biodegradation in wastewater}

The study of microbial methanol and FA biodegradation in wastewater is an important problem of environmental biotechnology. Different microorganisms are capable of FA degradation: bacteria Pseudomonas spp. (Kato et al., 1983), Halomonas spp. (Azachi et al., 1995) and various strains of Methylotropha (Attwood \& Quayle, 1984); the yeasts of genera Debariomyces and Trichosporon (Kato et al., 1982), Hansenula (van Dijken et al., 1975), Candida (Pilat \& Prokop, 1976) and the fungi Gliocladium (Sakagushi et al., 1975). Selected strains of Pseudomonas putida, Pseudomonas cepacia, Trichosporon penicillatum and the mixed culture of these three species were used for aerobic degradation of FA and formic acid in synthetic medium and wastewater generated by melamine resin production (Glancer-Šoljan et al., 2001). The selected mixed culture containing two bacterial strains of Pseudomonas (P. putida and $P$. cepacia) and Trichosporon yeast genera (T. peicillatum) exhibited highly efficient degradation of FA and formic acid in the synthetic medium. The mixed culture also degraded formaldehyde, methanol and butanol contained in the wastewater of the melamine resin production facility.

Nineteen bacterial strains able to degrade and metabolize FA as a sole carbon source were isolated from soil and wastewater of a FA production factory. The samples were cultured in complex and mineral salts media containing $370 \mathrm{mg}$ FA/L. Some strains were identified to be Pseudomonas pseudoalcaligenes, P. aeruginosa, P. testosteroni, P. putida, and Methylobacterium extorquens. After adaptation to high concentrations of FA, microorganisms completely consumed $3.7 \mathrm{~g} \mathrm{FA} / \mathrm{L}$ after $24 \mathrm{~h}$, and degraded $70 \%$ of $5.92 \mathrm{~g} \mathrm{FA} / \mathrm{L}$ after $72 \mathrm{~h}$ (Mirdamadi et al., 2005). The development of appropriate technologies for the treatment of FA discharged 
into the environment is important to minimize its negative impact. Studies have shown that in a special reactor for treating FA, both Methanosaeta and Methanosarcina were found to thrive with influent FA concentrations higher than $394.0 \mathrm{mg} \mathrm{HCHO} / \mathrm{L}$. Microorganisms like Methanosaeta probably survived due to its preferential use of acetate while Methanosarcina preferentially used the methanol (Oliveira et al., 2004). Biodegradation of FA was also tested in the marine microalga Nannochloropsis oculata (Yoshida et al., 2009). Transformation of $\left[{ }^{13} \mathrm{C}\right]-\mathrm{FA}$ in the medium was monitored by nuclear magnetic resonance (NMR) spectrometry. FA was transformed into formate, and these two substances degraded in the medium as was clearly shown by the NMR spectrometry.

Environmental FA can be detected and remediated in a biological system that incorporates a bacterium Rhodobacter sphaeroides containing suitable genetic sequences encoding a FAinducible regulatory system. The system includes a transcriptional promoter from Rhodobacter sphaeroides that can be specifically induced in the presence of FA to transcribe an operable linked gene (US Patent 6242244).

The application of the methylotrophic yeast Hansenula polymorpha to the treatment of methanol and FA containing wastewater was experimentally verified. A variety of wastewater samples originating from chemical industry effluent were examined (Kaszycki \& Kołoczek, 2000; Kaszycki et al., 2001). The methylotrophic yeast $H$. polymorpha was shown to cooperate with activated sludge from biological wastewater treatment stations, enhancing substantially its potential to biodegrade FA in industrial wastewater. After integration with yeast cells, the modified sludge retained its original structure and activity whereas its resistance to elevated FA concentrations was significantly improved (Kaszycki \& Koloczek, 2002). An yeast isolate revealing unique enzymatic activities and substrate-dependent polymorphism was obtained from the autochthonous microflora of soil heavily polluted with oily slurries. By means of standard yeast identification procedures, the strain was identified as Trichosporon cutaneum. Further molecular PCR product analysis of ribosomal DNA confirmed the identity of the isolate with the genus Trichosporon. As it grew on methanol as a sole carbon source, the strain appeared to be methylotrophic, able to utilize formaldehyde (Kaszycki et al., 2006).

Mitsui et al. (2005) isolated a bacterial strain that efficiently degraded FA and used it as a sole carbon source. The isolated strain was identified as Methylobacterium sp. MF1, which could grow on FA and methanol. The resistance to the toxic effects of FA exhibited by Methylobacterium sp. MF1 is related to factors other than C1 metabolism.

Microorganisms utilizing methanol have adopted several metabolic strategies to cope with the toxicity of FA. Mechanisms of FA detoxification in yeast, bacteria and archaea were studied (Yurimoto et al., 2005). The toxicity of FA in batch assays, using volatile fatty acids as co-substrates and the continuous anaerobic treatment of wastewaters containing FA in upflow anaerobic sludge blanket reactors was investigated (Vidal et al., 1999). The kinetic process of FA biodegradation in a biofilter packed with a mixture of compost, vermiculite powder and ceramic particles was studied by Xu et al. (2010).

\section{FA-oxidizing yeast enzymes for FA monitoring}

\section{1 $\mathrm{NAD}^{+}$- and glutathione-dependent formaldehyde dehydrogenase (FdDH) 4.1.1Yeast engineered for overproduction of $\mathrm{FdDH}$}

To construct strains of $H$. polymorpha that over-produce thermostable $\mathrm{NAD}^{+}-$and glutathione-dependent $\mathrm{FdDH}$, the $H$. polymorpha FLD1 gene with its own promoter 
(Baerends et al., 2002) was inserted into the integrative plasmid pYT1 (Demkiv et al., 2005) containing the LEU2 gene of Saccharomyces cerevisiae (as a selective marker). The constructed vector was used for multi-copy integration of the target gene into the genome of $H$. polymorpha by transformation of leu 1-1 (Demkiv et al., 2005) and leu 2-2 recipient cells (both leu alleles are complemented by S. cerevisiae gene LEU2). The transformation was performed using three different methods (Table 1): electroporation (Delorme, 1989), the lithium chloride method (Ito et al., 1983), and the protoplasting procedure (Hinnen et al., 1978).

Selection of FdDH-overproducing strains was carried out simultaneously by leucine prototrophy and by resistance to elevated FA concentrations in the medium. Of more than 150 integrative $\mathrm{Leu}^{+}$- transformants with higher resistance to FA - up to 10-12 $\mathrm{mM}$ on solid plates, 14 stable clones, resistant up to 15-20 mM FA on plates, were selected and studied in more detail. The growth characterstics of selected clones in the liquid medium were shown in Fig.1: all transfomants grew better and were more resistant to elevated FA content in liquid medium with $1 \%$ methanol, compared to the recipient strains (Demkiv et al., 2005, Gayda et al, 2008). Finally, FdDH specific activities were tested in cell-free extracts (CE) of the best selected FA-resistant Leu-prototrophic transformants (Fig. 2).

\begin{tabular}{|c|c|c|c|c|c|}
\hline $\begin{array}{c}\text { Parental } \\
\text { strains }\end{array}$ & $\begin{array}{c}\text { Transformation } \\
\text { method }\end{array}$ & Plasmid & $\begin{array}{c}\text { Number of } \\
\text { experiments }\end{array}$ & $\begin{array}{c}\text { Average } \\
\text { transformation } \\
\text { efficacy, Leu }{ }^{+}- \\
\text {clones } / \mu \mathrm{g} \text { DNA }\end{array}$ & $\begin{array}{l}\text { Number of the } \\
\text { tested clones } \\
\text { with a higher } \\
\text { resistance to FA }\end{array}$ \\
\hline Leu1-1 & \multirow{4}{*}{ Electroporation } & pHpFLD1 & 3 & $2 \times 10^{3}$ & 12 \\
\hline Lеu2-2 & & pHpFLD1 & 3 & 30 & 10 \\
\hline Leu1-1 & & $\mathrm{pHp}(\mathrm{FLD} 1)_{2}$ & 3 & $1.5 \times 10^{3}$ & 50 \\
\hline Leu2-2 & & $\mathrm{pHp}(\mathrm{FLD} 1)_{2}$ & 3 & 15 & 10 \\
\hline Leu1-1 & \multirow{2}{*}{$\mathrm{LiCl}$} & pHpFLD1 & 3 & 2 & 12 \\
\hline Leu2-2 & & pHpFLD1 & 3 & 20 & 80 \\
\hline Leu1-1 & \multirow{2}{*}{ Protoplastes } & $\mathrm{pHp}(\text { FLD1 })_{2}$ & 1 & 0.5 & 1 \\
\hline Leu2-2 & & $\mathrm{pHp}^{\mathrm{pHLD} 1)_{2}}$ & 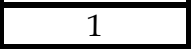 & 0.4 & 2 \\
\hline
\end{tabular}

Table 1. Efficacy of different transformation methods for two strains of the yeast $H$. polymorpha by plasmids $p H p F L D 1$ and $p H p(F L D 1)_{2}$

Activity of $\mathrm{FdDH}$ was determined by the rate of $\mathrm{NADH}$ formation monitored spectrophotometrically at $340 \mathrm{~nm}$ (Schutte et al., 1976). One unit (1 U) of the enzyme activity was defined as the amount of the enzyme which forms $1 \mu$ mole NADH per min under standard conditions of the assay: $25^{\circ} \mathrm{C}, 1 \mathrm{mM}$ FA, $1 \mathrm{mM} \mathrm{NAD}^{+}, 2 \mathrm{mM}$ GSH in $50 \mathrm{mM}$ Phosphate buffer (PB, $\mathrm{pH} 8.0)$.

Tf 11-6 and Tf-142 were the most effective recombinant strains, with the highest FdDH activity, up to $4.0 \mathrm{U} / \mathrm{mg}$, which is a $4-5$ fold increased as compared to the parental strains, leu 1-1 and leu 2-2, respectively. These transformants were characterized and chosen as a source for FdDH production. It was estimated by Southern dot-blot analysis, that genomes of the stable recombinant yeast clones contain 6-8 copies of the target FLD1 gene, which confirmed the results obtained by the Southern-hybridization method (data not shown). Therefore, the recombinant yeast strain Tf 11-6 contains more than 8 copies of the integrated plasmid, as compared to 1 copy of the parental strain, probably due to the usage of the double-gene plasmid $\mathrm{pHp}(\mathrm{FLD1})_{2}$ and its tandem integration into the genome of the recipient strain. 

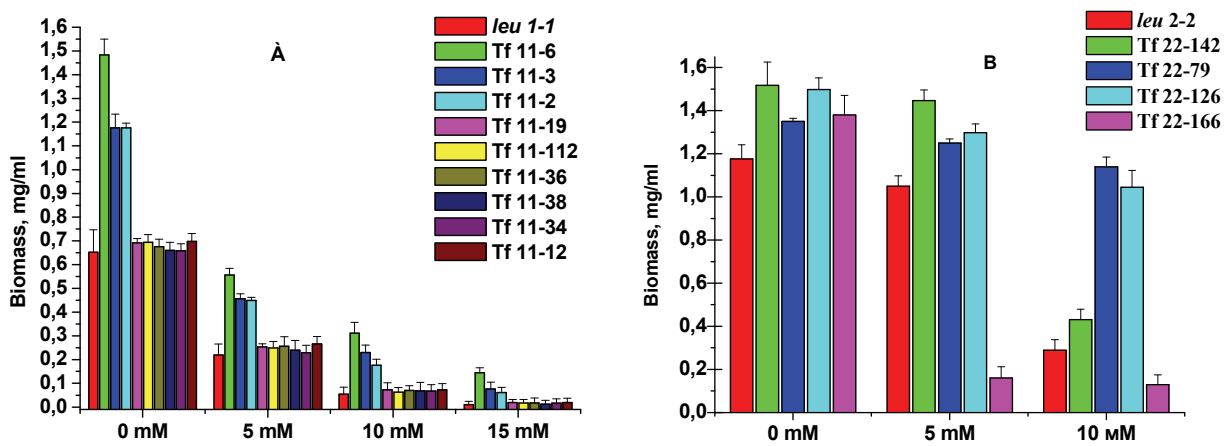

Fig. 1. Resistance to FA of the recipient yeast strains leu1-1(A) and leu2-2 (B), of H. polymorpha and their transformants, grown in $1 \%$ methanol medium
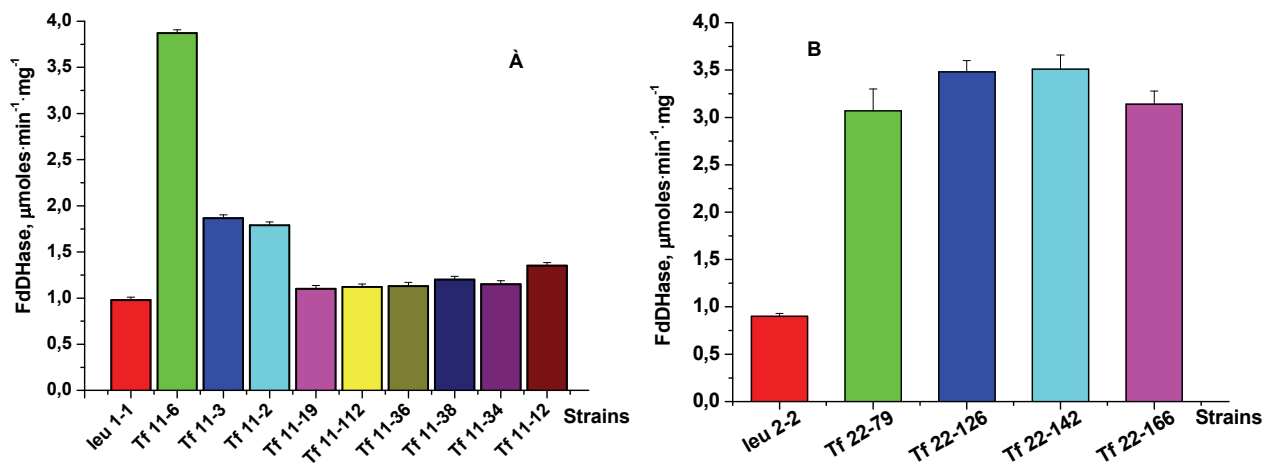

Fig. 2. Specific activity of FdDH in cell-free extracts of parental yeast strains leu1-1(A) and leu 2-2 (B) of H. polymorpha and their transformants grown in 1\% methanol medium

\subsubsection{Optimization of cultivation conditions for FdDH-overproduction}

In order to optimize cultivation conditions to obtain the highest enzyme yield, the influence of growth medium composition on FdDH concentration using the two best strains, Tf 11-6 and Tf 22-142, was studied. FdDH activity in cell-free extract was dependent on a carbon source. Cultivation in 1\% methanol as a sole carbon source resulted in the highest levels of the enzyme synthesis for both of the tested strains (Fig. 3), which is in accordance with the literature concerning the wild type strains (Hartner et al., 2006; Harder et al.,1989; Egli et al.,1982).

The addition of FA to the methanol medium stimulated synthesis of FdDH. Under experimentally determined optimal conditions, i.e. methanol as carbon source, methylamine as nitrogen source and $5 \mathrm{mM} \mathrm{FA}$ as an additional inductor of $\mathrm{FdDH}$ synthesis, target 


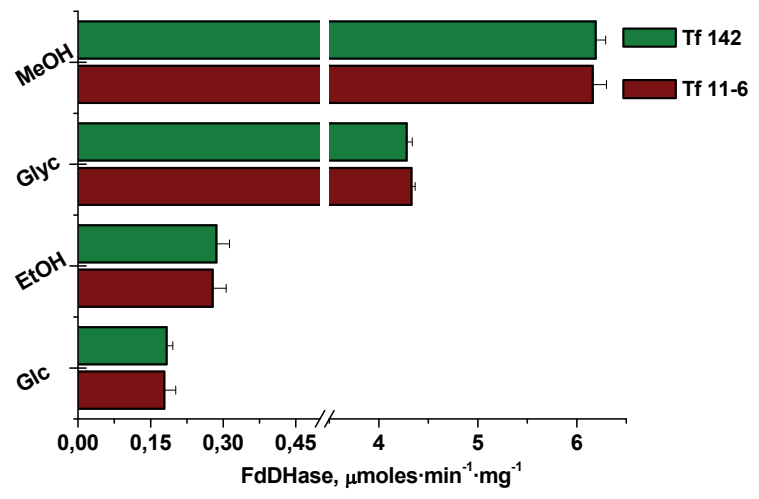

Fig. 3. FdDH activity in CE of the recombinant strains Tf 11-6 and Tf 142 , cultivated on the media with methylamine, $5 \mathrm{mM}$ FA and different carbon sources: $1 \%$ ethanol (EtOH), $1 \%$ methanol (MeOH), $1 \%$ glucose (Glc) or glycerol (Glyc).

enzyme activity achieved was $6.2 \mathrm{U} / \mathrm{mg}$, 1.6-fold higher than under normal growth conditions, as described in Fig. 2. The addition of up to $10 \mathrm{mM}$ FA to the optimal culture medium resulted in $\mathrm{FdDH}$ activity of $8.3 \mathrm{U} \mathrm{mg}^{-1}$, a 2-fold increase as compared to medium without FA (Fig.2). The strong correlation between FA concentration in the medium and FdDH activity in cultivated cells of recombinant yeast strain Tf-11-6, demonstrates the important role of FA as a FdDH-synthesis inducer (Fig. 4).

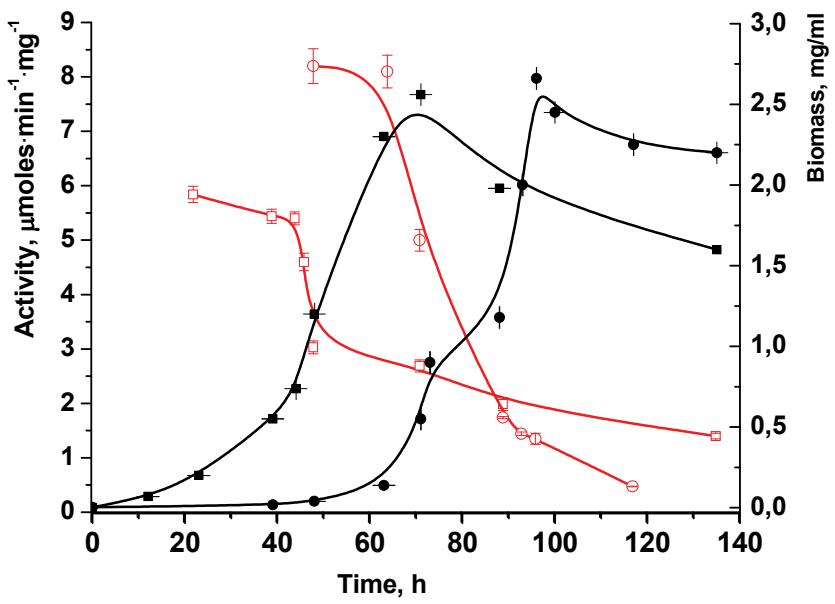

Fig. 4. FdDH activity (red), and biomass (black) of the enzyme-overproducer Tf-11-6 during cultivation in a medium with $1 \%$ methanol supplemented with $5 \mathrm{mM}(\boldsymbol{\square}, \mathbf{\square})$ and $10 \mathrm{mM}(\bullet, 0)$ formaldehyde. 


\subsubsection{FdDH purification and characterization}

For enzyme isolation from cell-free extracts, cells of the recombinant over-producer strain Tf 11-6, cultivated in $1 \%$ methanol medium supplemented with $5 \mathrm{mM}$ FA during $20 \mathrm{~h}$, were used. A simple scheme for $\mathrm{FdDH}$ isolation and purification on anion-exchange sorbent was proposed, resulting in a FdDH preparation with specific activity about $27 \mathrm{U}$ units per $\mathrm{mg}$ of protein. For comparison, specific activities of commercially available $\mathrm{FdDH}$ preparations from Ps. putida and from the yeast $C$. boidinii are 3-5 $\mathrm{U} \mathrm{mg}^{-1}$ and $17-20 \mathrm{Umg}^{-1}$, respectively (Demkiv, et. al. 2007). The purity of the isolated enzyme preparation was controlled by PAAG electrophoresis in denaturizing conditions (Laemmly, 1970).

Some physico-chemical characteristics of the purified FdDH are shown in Table 2.

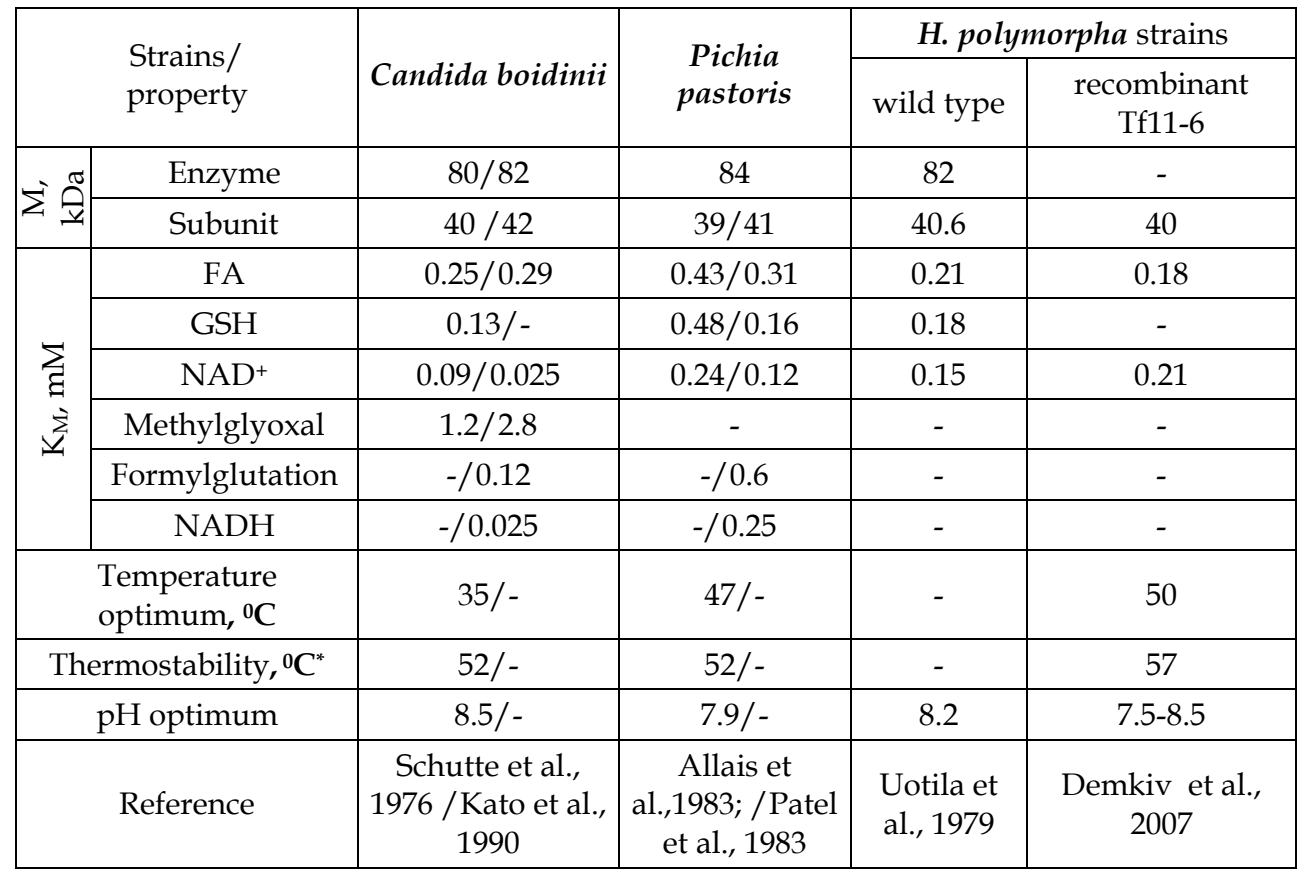

Table 2. Comparison of structural and enzymatic properties of $\mathrm{FdDH}$.

The molecular mass of the FdDH subunit, estimated by SDS-electrophoresis, was shown to be approximately $40 \mathrm{kDa}$, similar to the $41 \mathrm{kDa}$ found for C. boidinii (Melissis et al., 2001). It was reported that the predicted FLD1 gene product (Fld1p) is a protein of 380 amino acids (Baerends et al., 2002). Taking into account, that the $\mathrm{M}$ of the native enzyme from various methanol-utilizing yeasts were estimated to be from 80 to $85 \mathrm{kDa}$, isolated thermostable, $\mathrm{NAD}^{+}$- and GSH-dependent FdDH can be assumed to be dimeric. As shown in Table 2, values of the Michaelis-Menten constant $\left(\mathrm{K}_{\mathrm{M}}\right)$ for FA and $\mathrm{NAD}^{+}$calculated for this enzyme are close to $\mathrm{K}_{\mathrm{M}}$ for the wild-type enzyme.

Optimal pH-value and $\mathrm{pH}$-stability (during incubation in the appropriate buffer at room temperature for $60 \mathrm{~min}$ ) of the enzyme were evaluated. Optimal $\mathrm{pH}$ was found to be in the range of 7.5-8.5, and the highest stability of $\mathrm{FdDH}$ was observed at $\mathrm{pH} 7.0-8.5$. 
The optimal temperature for enzyme activity was $50^{\circ} \mathrm{C}$. At $65^{\circ} \mathrm{C}$ the enzyme retained about $60 \%$ of its highest activity (assay time $5 \mathrm{~min}$ ), i.e. equal to the level of $\mathrm{FdDH}$ activity at $30^{\circ} \mathrm{C}$. The enzymatic activity at $37^{\circ} \mathrm{C}$ was 1.6 -fold higher than under the standard conditions of the $\mathrm{FdDH}$ activity assay $\left(\right.$ at $25^{\circ} \mathrm{C}$ ). Study of the thermal stability of the enzyme demonstrated that its activity was completely preserved after $10 \mathrm{~min}$ of incubation at $40^{\circ} \mathrm{C}$, and was partially preserved at $55^{\circ} \mathrm{C}$ (up to $70 \%$ ) and $60^{\circ} \mathrm{C}(25 \%)$. Complete inactivation occurred after heating of the enzyme solution at $70^{\circ} \mathrm{C}$ for $5 \mathrm{~min}$. These results indicate that the thermostability of the enzyme is apparently high, enabling its usage for bioanalytical purposes, namely, for FA assay in food products, wastewater, and pharmaceuticals, as well as for biotransformation of FA to formic acid.

The effect of a number of inhibitors on the enzymatic properties was studied. Table 3 shows an influence of some compounds on enzymatic activity in purified $\mathrm{FdDH}$ preparation tested before and after its incubation with additives, for $30 \mathrm{~min}$ at $4^{\circ} \mathrm{C}$. Bivalent cations $\left(\mathrm{Zn}^{2+}, \mathrm{Cu}^{2+}\right.$ and $\left.\mathrm{Mn}^{2+}\right)$, as well as an ionic detergent SDS were shown to inhibit FdDH activity. According to the literature, enzymes from two other yeasts, P. pastoris and C. boidini (Allais et al., 1983; Kato et al., 1990, Patel, 1983) were also inhibited in a similar fashion.

\subsection{Enzymatic methods for FA monitoring}

\subsubsection{The development of FdDH- and AOX based enzymatic kits}

$\mathrm{FdDH}$ preparation isolated from the recombinant strain of the yeast $H$. polymorpha with the specific activity 17.0 units per mg of protein at $25^{\circ} \mathrm{C}$ (that is about $27 \mathrm{U} \mathrm{mg}^{-1}$ at $37^{\circ} \mathrm{C}$ ) was proposed for the enzymatic assay of FA. In methylotrophic yeasts, $\mathrm{NAD}^{+}$- and glutathionedependent $\mathrm{FdDH}$ catalyzes the oxidation of FA to formic acid with the simultaneous reduction of $\mathrm{NAD}^{+}$to $\mathrm{NADH}$.

\begin{tabular}{|c|c|c|}
\hline \multirow{2}{*}{ Additive } & \multicolumn{2}{|c|}{$\begin{array}{c}\text { FdDH activity (\%) } \\
\text { under different additives levels }\end{array}$} \\
\cline { 2 - 3 } & $1 \mathrm{mM}$ & $10 \mathrm{mM}$ \\
\hline $\mathrm{ZnSO}_{4}$ & 23.3 & 0 \\
\hline $\mathrm{CuSO}_{4}$ & 0 & 38.3 \\
\hline $\mathrm{FeCl}_{3}$ & 78.3 & 60.0 \\
\hline $\mathrm{MnCl}_{2}$ & 27.8 & 85.0 \\
\hline $\mathrm{MgCl}_{2}$ & 84.8 & 85.0 \\
\hline EDTA & 96.5 & 56.3 \\
\hline PMSF & 91.7 & 66.7 \\
\hline 2-mercaptoethanol & 72.7 & 0 \\
\hline SDS & 0 & 85.2 \\
\hline Dithiotreitol & 96.33 & $0 \mathrm{c}$ \\
\hline
\end{tabular}

Table 3. The influence of different additives, in concentrations 1 and $10 \mathrm{mM}$, on enzymatic activity of purified FdDH preparation (100\% activity has initial enzyme preparation)

The proposed enzymatic method is based on the photometric detection of colored product, formazan, formed from nitrotetrazolium blue (NTB) in reaction coupled to FdDH-catalyzed oxidation of FA in the presence of an artificial mediator, phenasine methosulfate (PMS) and detergent Triton X-100 (Demkiv et al., 2007, Demkiv et al., 2009): 
$\mathrm{NADH}+\mathrm{NTB}^{+} \longrightarrow \mathrm{NAD}^{+}+$Formazan

The enzymatic kit "Formatest" was developed on the base of these reagents. The assay was performed in conditions of incomplete conversion of the analyte (approximately, $10 \%$ ), using a limited concentration of the enzyme $(23 \mathrm{mU} / \mathrm{ml})$ in the reaction mixture. These conditions are economic and reasonable, because of the high FA content in the tested samples. Under conditions of complete oxidation of FA (excess of the enzyme), assay sensitivity was determined to be $2.5 \mu \mathrm{M}$ (in final reaction mixture) or $20 \mu \mathrm{M}$ in the tested samples.

Alcohol oxidase (AOX) from the thermotolerant methylotrophic yeast cells $H$. polymorpha can be an alternative to $\mathrm{FdDH}$, used for analytical purposes. This enzyme is quite stable, contains tightly bound FAD and does not need any exogenous co-enzyme for catalytic activity (Woodward J., 1990). Theoretically, AOX can be used to assay FA because in aqueous solutions FA exists in hydrated form (95-99\% of total concentration) which structurally resembles methanol, and can be oxidized by AOX with the subsequent formation of formic acid and hydrogen peroxide (see reactions 4 and 5).

AOX preparations were isolated from the strain $H$. polymorpha C-105 - catalase-defective mutant (Gonchar et al., 1990) with impaired glucose catabolite repression of AOX synthesis (gcr1, catX). The mutant cells, grown in glucose medium, were disrupted and cell-free extract was used for partial purification of AOX by two-step ammonium sulfate precipitation (Gonchar et al., 1998). Using this simple procedure, enzyme preparation in a form of suspension in $60 \%$ saturated $\left(\mathrm{NH}_{4}\right)_{2} \mathrm{SO}_{4}$, with specific activity of $7.5 \mathrm{U} / \mathrm{mg}$, was obtained. This is close to activity of some commercial AOX preparations. As shown by PAAG electrophoresis, the isolated crude AOX preparation is not homogenous, but still suitable for analytical application. AOX preparation can be stored at $4{ }^{\circ} \mathrm{C}$ in $60 \%$ saturated ammonium sulfate in the presence of protease inhibitors for at least 1 year without loss of activity.

The oxidase-peroxidase-based method (AOP) and enzymatic kit "Alcotest" were developed on the base of two enzymes - alcohol oxidase (AOX) and peroxidase (PO) (Gonchar et al., 2001). As a chromogen, 3,3',5,5'-tetramethyl-benzidine dihydrochloride (TMB) was used. The principle of FA determination by AOP-method is based on the measurement of the dyeproduct accumulation in peroxidative oxidation of chromogen by $\mathrm{H}_{2} \mathrm{O}_{2}$ (Sibirny et al., 2008) generated from FA in AOX reaction (see reactions 5, 7):

$$
\begin{aligned}
& \mathrm{H}_{2} \mathrm{O}_{2}+\mathrm{S}-[2 \mathrm{H}]_{\text {reduced }} \stackrel{P O}{\longrightarrow} 2 \mathrm{H}_{2} \mathrm{O}+\mathrm{S}_{\mathrm{ox}} \\
& \text { chromogen dye }
\end{aligned}
$$

The analytical parameters of the FdDH-based method have been determined (Fig. 5) in comparison with enzymatic AOP-method and several chemical methods based on the use of Nash's reagent, 4-amino-3-hydrazino-5-mercapto-1,2,4-triazole (Purpald), chromotropic acid and 3-methyl-2-benzothiazolinone hydrazone hydrochloride (MBTH). It was clearly shown, that AOP-method has the highest sensitivity. The slope of the corresponding calibration curve is equal 59.3, corresponding to an apparent millimolar extinction of the formed coloured product (in $\mathrm{mM}^{-1} \mathrm{~cm}^{-1}$ ). Actually, the observed slope value equals the millimolar extinction coefficient $\left(\varepsilon_{\mathrm{mM}}\right)$ multiplied by conversion factor for the enzymatic reaction $(\mathrm{k})$ :

$$
\text { Slope }=\varepsilon_{\mathrm{mM}} \times \mathrm{k}
$$


The value of $\varepsilon_{\mathrm{mM}}$ for the oxidized TMB is equal $81.7 \mathrm{mM}^{-1} \mathrm{~cm}^{-1}$ (Gonchar et al., 2001), so the conversion coefficient of the analyte for AOP-method at the used experimental conditions is $72.6 \%$. For the FdDH-based method, conversion factor of the analyte is $32.9 \%$, assuming a milimolar extinction for NTB-formazane as $10.2 \mathrm{mM}^{-1} \mathrm{~cm}^{-1}$ at $570 \mathrm{~nm}$ in acidic medium.

The linearity of calibration curve for AOP-method is kept even at high optical densities - up to 0.9 which corresponds to $15 \mu \mathrm{M}$ FA in final reaction mixture $\left(15 \mathrm{nmol} \mathrm{ml}^{-1}\right)$, and the threshold sensitivity of the method is about $0.8 \mathrm{nmol} \mathrm{ml}^{-1}$. These analytical parameters are the best as compared to four chemical methods, even with the use of MBTH or Purpald.

FdDH-based method reveals linearity (at enzymatic conversion above $33 \%$ ) at least to $100 \mu \mathrm{M}$ FA, and its sensitivity is close to Nash's method (the corresponding slopes are 3.36 and 4.46, respectively). Compared to AOP-method, sensitivity of FdDH-based-method is 18-fold less.

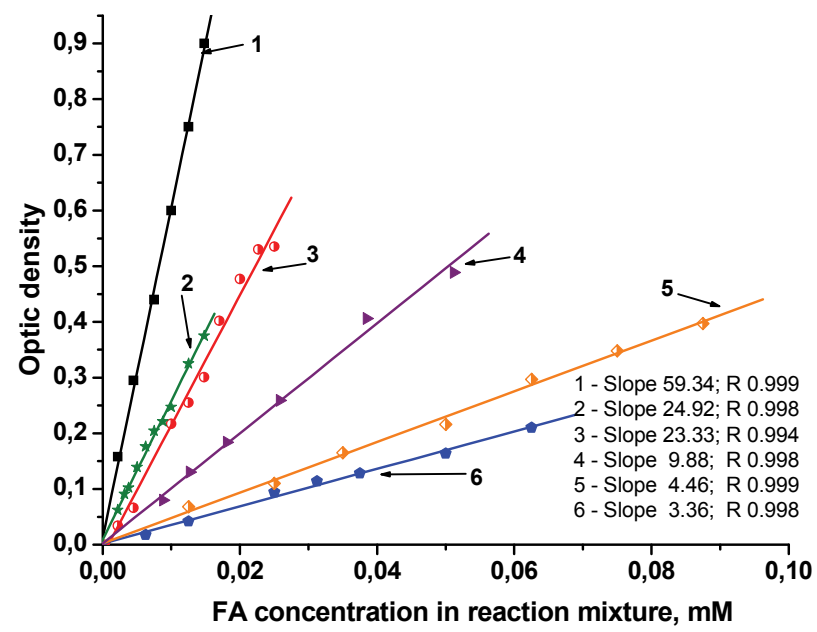

Fig. 5. Comparative analysis of FA-assay methods, using: 1- AOX and PO (AOP); 2 - MBTH; 3 - "Purpald"; 4 -chromotropic acid; 5 - Nash's reagent and 6 - FdDH. The slopes of calibration curves characterize the sensitivity of the methods. Slope values and coefficients of linear regression are shown for each calibration curve.

\subsubsection{The reliability of the enzymatic methods for assay of FA in real samples}

The FdDH- and AOX-based methods were tested on the real wastewater samples containing FA. We have tested FA in real samples of wastes by the developed enzymatic methods in comparison with standard chemical approaches. It has been demonstrated that in order to evaluate the possible interfering effect of real samples' components on FA assay, it was necessary to perform a standard addition test in both approaches (chemical and enzymatic) and that analytical data obtained by enzymatic method are more reliable than chemical ones.

As shown in Table 4, the comparison of FA concentrations for the FdDH- and AOX-based methods and two routinely used chemical ones (chromotropic acid and MBTH), showed a good correlation between the four approaches. Only in some cases (samples of wastewater DK5 and DK7), with a lower FA content, the difference between the compared methods is higher, than $15 \%-41 \%$ and $26 \%$, respectively. A relatively high difference is also observed between two chemical methods for the mentioned above samples $-37 \%$ and $21 \%$. This can 
be explained by a higher error in measurement of low optical density values obtained for samples with a low FA content. On the other hand, it is worth emphasizing that the chemical approaches used are not free from possible mistakes due to interference from coimpurities, usually present in wastewater samples, for example, phenol, which is an attendant pollutant of FA-containing wastes (Polish standard, 1988).

To evaluate the possible interfering effect of the components of wasterwater samples on FA assay by the FdDH-based and chromotropic acid methods, we used a standard addition test (SAT) for sample WW-A (Table 4, Fig. 6A and B).
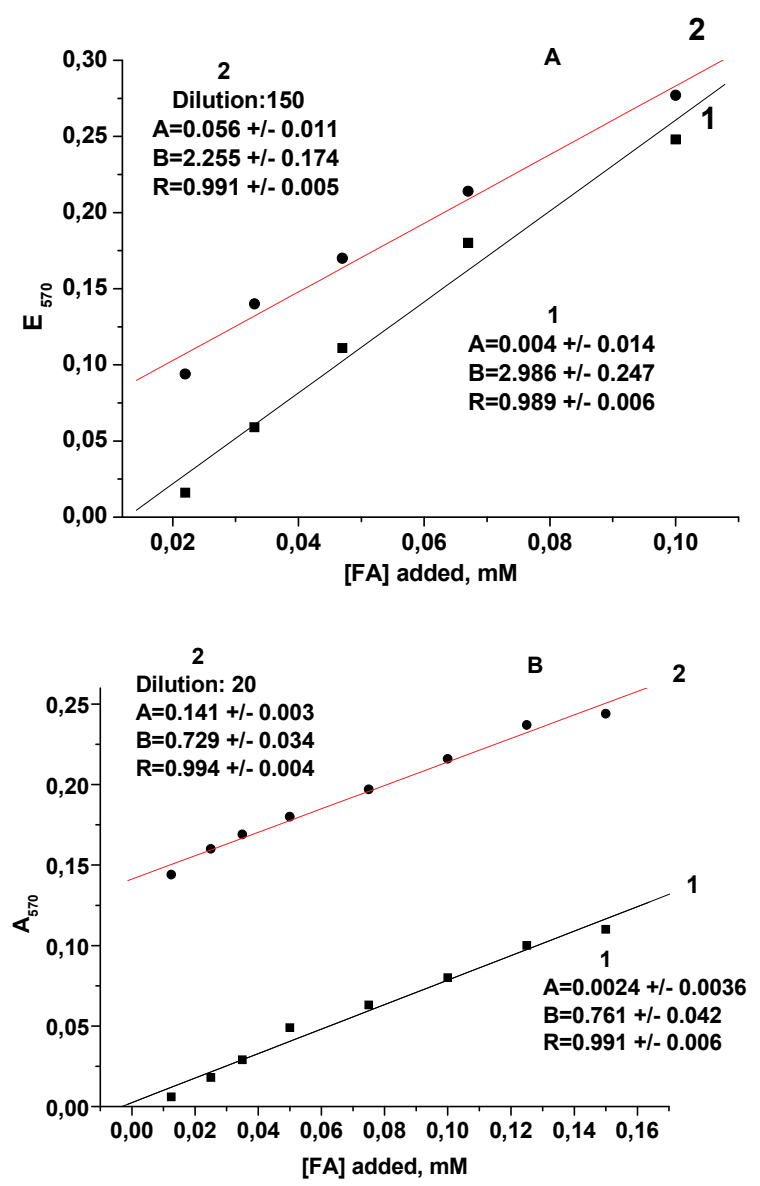

Fig. 6. Standard addition test for the FA assay by the chromotropic acid method (A) and the FdDH-based method (B). Curve 1 corresponds to the calibration experiment performed for FA solutions (traditional calibration), and curve 2 corresponds to the standard addition calibration (FA was added at different concentrations to the diluted wastewater sample; WW-A). Some statistical data are presented on the graphs: parameters of linear regression (coefficients of the equation $\mathrm{Y}=\mathrm{A}+\mathrm{BX}$, where $\mathrm{Y}=\mathrm{OD}, \mathrm{X}=\mathrm{FA}$ concentration $(\mathrm{mM}), \mathrm{A}=\mathrm{OD}$ of the variant without addition of exogenous $\mathrm{FA}$, and $\mathrm{B}=$ slope value); $\mathrm{R}=$ linear regression coefficient. 


\begin{tabular}{|c|c|c|c|c|}
\hline \multirow{2}{*}{$\begin{array}{l}\text { Sample/ } \\
\text { Method }\end{array}$} & \multicolumn{2}{|c|}{ Enzymatic methods } & \multicolumn{2}{|c|}{ Chemical methods } \\
\hline & FdDH-based & AOX-based & $\begin{array}{l}\text { Chromotropic } \\
\text { acid }\end{array}$ & MBTH \\
\hline DK 1 & $7.89 \pm 0.59$ & $9.60 \pm 0.45$ & $9.30 \pm 0.61$ & $9.56 \pm 0.51$ \\
\hline DK 2 & $6.66 \pm 0.26$ & $8.12 \pm 0.20$ & $8.70 \pm 0.50$ & $8.06 \pm 0.32$ \\
\hline DK 3 & $6.88 \pm 0.41$ & $8.01 \pm 0.44$ & $7.20 \pm 0.33$ & $7.84 \pm 0.36$ \\
\hline DK 4 & $7.58 \pm 0.32$ & $6.86 \pm 0.9$ & $7.10 \pm 0.36$ & $6.30 \pm 0.46$ \\
\hline DK 5 & $2.32 \pm 0.08$ & $1.97 \pm 0.12$ & $1.65 \pm 0.35$ & $1.20 \pm 0.15$ \\
\hline DK 6 & $5.73 \pm 0.32$ & $5.60 \pm 0.28$ & $4.64 \pm 0.24$ & $4.99 \pm 0.06$ \\
\hline DK 7 & $2.47 \pm 0.15$ & $2.19 \pm 0.2$ & $1.62 \pm 0.17$ & $1.96 \pm 0.20$ \\
\hline WW-A & $\begin{array}{c}112 \pm 4.5 \text { (SAT) } \\
84.4 \pm 6.5 \\
\text { (routine test) }\end{array}$ & - & $\begin{array}{c}116 \pm 5.1 \text { (SAT) } \\
111 \pm 6.1 \text { (routine } \\
\text { test) }\end{array}$ & - \\
\hline
\end{tabular}

Table 4. Comparison of different methods for FA assay $(\mathrm{mg} / \mathrm{L})$ in wastewater samples

As can be seen from Fig. 6, the chromotropic method is more sensitive to the interfering effect of the wasterwater sample components than the enzymatic method: the slope values of the calibration curves obtained for FA in water and in the background of wasterwater sample (WW-A) differed by $24 \%$ (2.986 and 2.255, respectively). The respective values obtained for the enzymatic method were 0.761 and 0.729 , a difference of only $4.2 \%$, which is within the limit of statistical deviation. Thus, we can conclude that analytical data obtained by the FdDH-based method are more reliable than the chemical ones. Due to this very important analytical feature of the enzymatic method, it can be recommended for practical application in lieu of chemical methods, which are labour-intensive and time consuming, thereby eliminating the need to distil the samples or perform standard addition test (as in the case of phenol contamination).

The FdDH-based method was tested on different FA-containing vaccines (Paryzhak et al., 2007). As shown in Table 5, the comparison of FA concentration obtained by the FdDHbased method and by two routinely used chemical ones, showed a good correlation between both approaches. Lower levels of FA in anti-diphtheria vaccines, obtained using the enzymatic method as compared to the chemical methods may be due to the inhibitory effect on the enzyme by the $\mathrm{Hg}$-containing compound, $0.01 \%$ merthiolate, a vaccine preservative.

\begin{tabular}{|c|c|c|c|}
\hline \multirow{2}{*}{$\begin{array}{c}\text { Sample/ } \\
\text { Method }\end{array}$} & Enzymatic methods & \multicolumn{2}{|c|}{ Chemical methods } \\
\cline { 2 - 4 } & FdDH-based & Chromotropic acid & MBTH \\
\hline $\begin{array}{c}\text { Anti-diphtheria } \\
\text { vaccine }\end{array}$ & $15 \pm 2.5$ & $36 \pm 1.4$ & $31 \pm 2.0$ \\
\hline $\begin{array}{c}\text { Anti-diphtheria and } \\
\text { tetanus vaccine }\end{array}$ & $17 \pm 1.9$ & $27 \pm 2.0$ & $29 \pm 2.7$ \\
\hline Polio-vaccine "Imovax" & $30 \pm 3.0$ & $27 \pm 2.6$ & - \\
\hline \hline Tetanus vaccine & $10.2 \pm 0.6$ & $9.0 \pm 0.2$ & $12.0 \pm 0.2$ \\
\hline
\end{tabular}

Table 5. Comparison of FA assay methods $(\mathrm{mg} / \mathrm{L})$ in the different vaccines 


\subsubsection{AOX based method for simultaneous assay of methanol and FA in industrial wastewater}

We describe a new enzymo-chemical method for the simultaneous assay of methanol and FA in mixtures, which exploits AOX and aldehyde-selective reagent - 3-methyl-2benzothiazolinone hydrazone, MBTH (Sibirny et al., 2008). Pre-existing FA content is detected without treating samples by $\mathrm{AOX}\left(\mathrm{CD}_{0}\right.$ in reaction 9); and methanol content is determined by an increase in colored product concentration due to the methanol-oxidising reaction $\left(\mathrm{CD}_{\Delta}\right.$ in reaction 10$)$.

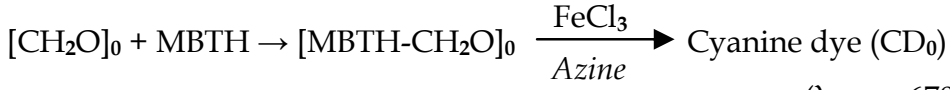

$$
\begin{aligned}
& (\lambda \max =670 \mathrm{Hм}) \\
& \mathrm{CH}_{3} \mathrm{OH}+\mathrm{O}_{2} \stackrel{A O X}{\longrightarrow}\left[\mathrm{CH}_{2} \mathrm{O}\right]_{\Delta} \stackrel{\mathrm{MBTH}}{\longrightarrow}\left[\mathrm{MBTH}-\mathrm{CH}_{2} \mathrm{O}_{\Delta} \underset{-\mathrm{H}_{2} \mathrm{O}_{2}}{\longrightarrow} \text { Cyanine dye }\left(\mathrm{CD}_{\Delta}\right)\right.
\end{aligned}
$$

Methanol is oxidized to FA by AOX, and FA is oxidized further by AOX. In the presence of $\mathrm{MBTH}, \mathrm{FA}$ reacts with MBTH, to form an azine adduct that prevents the further enzymatic oxidation of FA by AOX. In this reaction MBTH plays a double role. During the first step of reaction, it forms a colorless azine adduct with pre-existing and enzymatically formed FA, and masks it from further oxidation by AOX, and during the second step of reaction, MBTH facilitates the non-enzymatic oxidation of the azine product to cyanine dye in the presence of ferric ions in acid medium. Pre-existing FA content is assayed by colorimetric reaction with MBTH, without treating samples by AOX, and methanol content is determined by a gain in a colored product due to methanol-oxidising reaction. This enzymo-chemical method of differential detection of FA and methanol in mixtures was used to analyze samples of a commercial product, formalin, which is a concentrated FA solution containing methanol as a stabilizer that inhibits FA polymerization. The results of this analysis, shown in Table 6, are in a good agreement with the data obtained by traditional chemical methods and gas-chromatography.

\begin{tabular}{|c|c|c|c|c|c|}
\hline \multirow{2}{*}{ Sample } & \multicolumn{3}{|c|}{ Methanol (MeOH) and formaldehyde (FA) content, \% (M \pm m, $\mathrm{n}=4)$} \\
\cline { 2 - 6 } & \multicolumn{2}{|c|}{ AOX-chemical method } & $\begin{array}{c}\text { Gas- } \\
\text { chromatography }\end{array}$ & \multicolumn{2}{|c|}{$\begin{array}{c}\text { Chemical method } \\
\text { (chromotropic acid, } \\
\text { permanganate) }\end{array}$} \\
\hline & MeOH & FA & MeOH & MeOH & FA \\
\hline I & $2.59 \pm 0.19$ & $4.36 \pm 0.23$ & $3.3 \pm 0.5$ & $2.7 \pm 0.13$ & $4.62 \pm 0.11$ \\
\hline II & $4.61 \pm 0.34$ & $7.15 \pm 0.37$ & $5.39 \pm 0.5$ & $4.72 \pm 0.27$ & $7.27 \pm 0.2$ \\
\hline III & $3.29 \pm 0.38$ & $6.95 \pm 0.23$ & $3.4 \pm 0.5$ & $3.01 \pm 0.08$ & $6.49 \pm 0.28$ \\
\hline IV & $2.8 \pm 0.32$ & $6.23 \pm 0.25$ & $3.53 \pm 0.5$ & $2.70 \pm 0.05$ & $6.58 \pm 0.33$ \\
\hline V & 0 & $1.72 \pm 0.2$ & 0 & 0 & $1.85 \pm 0.1$ \\
\hline VI & 0 & $1.48 \pm 0.13$ & 0 & 0 & $1.73 \pm 0.08$ \\
\hline VII & $3.77 \pm 0.30$ & $2.66 \pm 0.16$ & $3.13 \pm 0.2$ & $3.79 \pm 0.12$ & $3.82 \pm 0.15$ \\
\hline VIII & $4.15 \pm 0.32$ & $2.14 \pm 0.27$ & $3.06 \pm 0.5$ & $2.93 \pm 0.31$ & $4.11 \pm 0.13$ \\
\hline
\end{tabular}

Table 6. Results of enzymo-chemical assay of methanol and FA in distillate of wastewaters (compared with the reference methods) 
The threshold sensitivity of the assay method for both analytes is near $1 \mu \mathrm{M}$ which corresponds to $30-32 \mathrm{ng}$ analyte in $1 \mathrm{ml}$ of reaction mixture and is 3.2-fold higher when compared to the chemical method using permanganate and chromotropic acid. The linearity of the calibration curve is reliable $(\mathrm{p}<0.0001)$ and standard deviation for parallel measurements of test samples does not exceed $7 \%$. The proposed method, in contrast to the standard chemical approach, does not need the use of aggressive chemicals (concentrated sulfuric, phosphoric, chromotropic acids, permanganate), it is easier to perform, and can be used for industrial waste verification and certification of formaline-containing materials.

\subsubsection{AOX- and FdDH-based methods for FA assay in fish food products}

Fish products are an important source of food protein. The fish species Gadidae are second only to Clupeidae in the size of industrial catch, but are preferred as food products whereas Clupeidae are more frequently used in agriculture and industry. The tissues of the Gadidae fish under inappropriate storage, that is, at non-deep freezing conditions $\left(t^{\circ}>-30{ }^{\circ} \mathrm{C}\right)$, accumulate highly toxic concentrations of FA due to endogenous metabolic reactions, involving namely the natural osmoprotectant trimethylamine-N-oxide, which acts as antifreeze (Reihbein, 1995). Generated FA can cause the fish to spoil, and even make it dangerous for human health if consumed. These two important reasons highlight the necessity for selective, sensitive and reproducible method to control the content of this dangerous metabolite in some fish products.

The applicability of both enzymes simultaneously used, AOX with peroxidase (AOPmethod) and FdDH for FA assay in fish products was demonstrated. Test samples of frozen fish of the Gadidae family (hake and cod), most frequently sold in European markets, as well as freshly-killed carp were used. The optimal protocols for obtaining of protein-free extracts and for testing procedures have been elaborated (Pavlishko et al., 2003). The analytical parameters of both enzymatic methods have been determined in comparison with several chemical methods based on the use of Nash's reagent, Purpald, chromotropic acid and MBTH. Fig. 5 presents calibration curves for the two enzymatic methods and compares them with the best of the chemical methods. It is clearly shown, the AOP-method has the highest sensitivity.

The FdDH-based method is nearly 18-fold less sensitive, compared to AOP-method, because of a lower molar extinction of the corresponding formazane: the analyte conversion factor is $32.9 \%$, assuming a milimolar extinction for NTB-formazane as $10.2 \mathrm{mM}^{-1} \mathrm{~cm}^{-1}$ at $570 \mathrm{~nm}$ in acidic medium (own data). FdDH-based method sensitivity is close to Nash's method (the corresponding slopes are 3.36 and 4.46, respectively). Linearity of FdDH-based method is at least to $100 \mu \mathrm{M}$ FA.

There was a good correlation between the analytical results of both enzymatic methods as compared with chemical approaches, though AOX-based assay is preferred due to its higher sensitivity, good linearity, insensitivity to the interference by test sample contaminants and the usage of non-aggressive reagents for the sample pre-treatment and assay procedure (Table 7 and Table 8).

Table 8 shows FA concentrations as measured by all of the tested methods. To compare the validity of both enzymatic methods, and to evaluate possible interference by the chemical background of the test samples on analytical results, FA content was analyzed using in fish protein-free extracts using a routine method (with an external calibration) as well as a multiple standard addition test (MSAT). Simultaneously, FA concentration was also analyzed by two chemical methods, using chromotropic acid and MBTH. 


\begin{tabular}{|c|c|c|c|}
\hline Fish & Hake & Cod & Carp \\
\hline AOX- based, $\mathrm{M} \pm \mathrm{m}$ & $90.0 \pm 2.6$ & $74.1 \pm 1.1$ & 0 \\
\hline Nash's, $\mathrm{M} \pm \mathrm{m}$ & $121.6 \pm 0.9$ & $96.8 \pm 3.1$ & 0 \\
\hline Purpald, $\mathrm{M} \pm \mathrm{m}$ & $100.6 \pm 1.6$ & $59.7 \pm 3.1$ & 0 \\
\hline
\end{tabular}

Table 7. Results of FA assay (in mg per $1 \mathrm{~kg}$ of wet weight of muscle tissue) in protein-free extracts of fish using three independent approaches: AOX- based method, Nash's and Purpald methods

\begin{tabular}{|l|c|c|}
\hline \multicolumn{1}{|c|}{ Method } & Multiple standard addition test & Routine test \\
\hline FdDH- based, $\mathrm{M} \pm \mathrm{m}$ & $101.8 \pm 3.2(\mathrm{p}<0.05)^{*}$ & $64.3 \pm 8.6$ \\
\hline AOX- based, $\mathrm{M} \pm \mathrm{m}$ & $95.3 \pm 3.7(\mathrm{p}>0.05)^{* *}$ & $98.0 \pm 3.5$ \\
\hline MBTH, $\mathrm{M} \pm \mathrm{m}$ & $104.3 \pm 5.6(\mathrm{p}>0.05)^{* *}$ & $106.4 \pm 7.9$ \\
\hline Chromotropic acid, $\mathrm{M} \pm \mathrm{m}$ & $100.5 \pm 1.2(\mathrm{p}>0.05)^{* *}$ & $102.8 \pm 7.3$ \\
\hline
\end{tabular}

${ }^{*}$ Difference between routine test and MSAT is statistically significant; ${ }^{* *}$ Difference between routine test and MSAT is statistically insignificant.

Table 8. Results of FA assay (in mg FA per kg of wet weight of muscle tissue) in protein-free extract of the fish hake, using three independent approaches: FdDH-metod, MBTH and chromotropic acid.

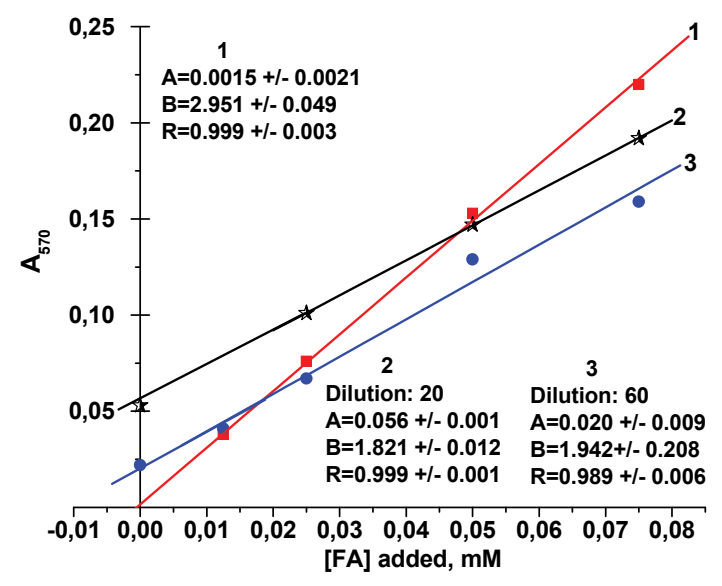

Fig. 7. Multiple standard addition test for FA assay in hake, using the FdDH-based method. Curve 1 corresponds to the calibration experiment performed for aqueous solutions of FA (external traditional calibration), and curves 2 and 3 correspond to the multiple standard addition test (FA was added at different concentrations to the diluted real sample). Some statistical data are presented on the graphs: parameters of linear regression (coefficients of the equation $Y=A+B X$, where $Y$ - optical density, $X$ - FA concentration (mM), A - optical density for the sample without addition of exogenous FA, and B - slope value); $\mathrm{R}$ - linear regression coefficient 
It was demonstrated that some fish products (hake and cod) contain high FA concentrations, up to $100 \mathrm{mg} / \mathrm{kg}$ wet weight, while FA content in carp was negligible.

The slopes of the calibration curves prepared on fish extracts are dependent upon the dilution factor, a bigger dilution results in a higher the slope (meaning there is less of an interfering effect). For the external calibration (that has no test sample background, and corresponds to an infinite dilution), the slope is the highest, 2.95 as compared to 1.94 (a 60-fold dilution of the test sample) and 1.82 (20-fold dilution of the sample). For the AOP and chemical methods, there is no significant difference between routine and MSAT-variants of the assay.

As shown in Table 8, there is a good correlation between all analytical data obtained in the MSAT-variant of analysis, which was not the case for the results obtained by the routine variant of analysis with external calibration. This may be due to the interference of some components which are co-extracted by TCA from the fish tissue. This suggestion is clearly supported by the data obtained by the FdDH-based method (Fig. 7).

\section{Construction and investigation of FA-selective biosensors}

\subsection{AOX- based enzymatic and microbial sensors}

For the quantitative analysis of FA there have been developed potentiometric biosensors using whole cells of mutant strains of methylotrophic yeasts and AOX as the biorecognition elements and $\mathrm{pH}$-Sensitive Field Effect Transistors (pH-SFETs) as a transducer. As an analytical signal in the pH-SFET-based sensor, the production of protons due to FA conversion into formic acid was exploited.

To develop cell-based FA - sensitive potentiometric sensor (Korpan et al., 1993), the mutant strain H. polymorpha A3-11 with repressed activities of AOX and formate dehydrogenase and blocked activity of formaldehyde reductase was obtained. The biosensor demonstrated high specificity/selectivity to FA with no response to several organic acids, methanol and other alcohols, except for the very low sensitivity to ethanol. The linear dynamic range of the sensor's response corresponds to FA concentration of 2 to $200 \mathrm{mM}$.

Partially purified AOX preparations have also been used as recognition elements of $\mathrm{pH}$ SFET-based potentiometric sensor selective to FA (Korpan et al., 1997; Korpan et al., 2000). The response time in steady-state measurement mode is in the range of 10-60 s, but if measured in kinetic mode the response time of the created biosensors was less than $5 \mathrm{~s}$. The linear dynamic range of the sensor output signals corresponds to 5-200 mM of FA concentration. It was quite suprisingly that AOX-based sensors gave no signal to methanol and was highly selective to FA. These results seem rather unusual because methanol is the preferred substrate for most AOX's, being directly oxidised to FA. The absence of a measurable response to methanol may be explained as follows: a) the rate of methanol oxidation in AOX reaction is about 10 -fold higher than that of FA; b) effective oxidation of methanol is likely to result in the local oxygen depletion in the bioactive zone limiting the oxygen available for subsequent FA oxidation; c) FA produced from methanol can diffuse from the bioactive zone back into the bulk solution without oxidation; d) FA, being very reactive, is likely to bind covalently with $\mathrm{NH}_{2}$-groups of AOX.

All these factors may result in a decrease of the concentration of formic acid produced from methanol in bioactive membranes to a level lower than the sensitivity of the potentiometric biosensor described and therefore no response to methanol is apparent. It is noteworthy that most of the described factors do not work for intact yeast cells where FA and methanol are oxidised in different reactions. 
It should be noted that contrary to other pH-SFET-sensors, the signal of AOX-based sensors (Korpan et al., 2000) to FA is not repressed, but even enhanced in the presence of Tris- $\mathrm{HCl}$ buffer. The chemical nature of this effect seems to be the reaction of FA with aminogroup of tris(hydroxymethyl)aminomethane with production of a hydroxymethylamine derivative, which is a weaker base compared to the parent compound and this reaction results in releasing free protons. This unexpected effect is the first reported example of specific "chemical enhancement" of the pH-SFET biosensor response.

A highly stable and sensitive amperometric bi-enzyme biosensor (Smutok et al., 2006) was developed for assay of ethanol, as well as of FA, using the highly-purified AOX preparation (Shleev et al., 2006), isolated from the yeast cells of H. polymorpha C-105. The sensor's layer was created with a non-manual electrochemically-induced immobilization procedure using a new type of Os-complex modified electrodeposition paints (EDP) for horseradish peroxidase placing in a first layer and a cathodic EDP for AOX immobilization and stabilization in a second layer. The used redox EDP assures fast electron transfer between the integrated peroxidase and the electrode surface at a low working potential.

Bioanalytical properties of an optimized biosensor such as response time, dynamic range for different analytes (FA and alcohols), operational and storage stability were investigated. The obtained sensors showed significantly improved stability as compared to previously reported sensors based on AOX. But such biosensor can be used for FA assay in wastes water only in the absence of aliphatic alcohols in tested probes.

For amperometric assay of FA, permeabilized and intact cells of the mutant strain $H$. polymorpha C-105 with a high activity of AOX as the biorecognition elements, were tested. Different approaches were used for monitoring FA-dependent cell response including analysis of their oxygen consumption rate by the use of a Clark electrode, as well as of oxidation of redox mediator at a screen-printed platinum electrode covered by cells entrapped in Ca-alginate gel. It was shown that oxygen consumption rate of permeabilized cells reached its saturation at $4 \mathrm{mM}$ of FA $\left(23^{\circ} \mathrm{C}\right)$. The detection limit is $0.27 \mathrm{mM}$. In the presence of redox mediator 2,6-dichlorophenolindophenol (DCIP), the screen-printed platinum band electrode covered by permeabilized cells did not show any current output to FA. In contrast, well-pronounced amperometric response to FA was observed in the case of intact yeast cells in the presence of DCIP. However, intact cells did not show a strict substrate selectivity, because of functioning of the whole electron transport chain. In contrast, essentially improved substrate selectivity was observed in the case of permeabilized cells where only AOX is responsible for the oxygen consumption. Obviously, it is necessary to perform a directed metabolic engineering of the yeast cells to improve their bioanalytical characteristics in the corresponding biosensors (Khlupova et al., 2007).

\subsection{FdDH-based capacitance, impedance and conductometric biosensors}

Recombinant yeast FdDH (Demkiv et al., 2007) was used as a FA-recognising element coupled with semiconductor-based structure $\mathrm{Si} / \mathrm{SiO}_{2} / \mathrm{Si}_{3} \mathrm{~N}_{4}$ as a transducer (Ben Ali et al., 2007). The bio-recognition element had a bi-layer architecture and consisted of FdDH, crosslinked with albumin, and two cofactors $\left(\mathrm{NAD}^{+}\right.$and GSH) in the high concentrations (first layer); the second layer was a negatively charged Nafion membrane which prevented a leakage of negatively charged cofactors from the bio-membrane. Changes in capacitance properties of the bio-recognition membrane were used for monitoring FA concentration in a bulk solution. It has been shown that FA can be detected within a concentration range from $10 \mu \mathrm{M}$ to $25 \mathrm{mM}$ with a detection limit of $10 \mu \mathrm{M}$ (Fig. 8 and Table 9). 
A similar FA sensitive biosensor based on commercial preparation of bacterial FdDH as recognizing element has been also described (Ben Ali et al., 2006). As transducers, gold electrodes $\mathrm{SiO}_{2} / \mathrm{Si} / \mathrm{SiO}_{2} / \mathrm{Ti} / \mathrm{Au}$ and electrolyte- insulator-semiconductor $\mathrm{Si} / \mathrm{SiO}_{2}$ structures (EIS) have been used. Changes in capacitance and impedance properties of the biorecognition membrane have been used for FA monitoring, It has been shown that FA can be detected within a concentration range from $1 \mu \mathrm{M}$ to $20 \mathrm{mM}$ depending on the used type of transduction, with a detection limit 1 or $100 \mu \mathrm{M}$ for gold- and EIS-based transducers, respectively.

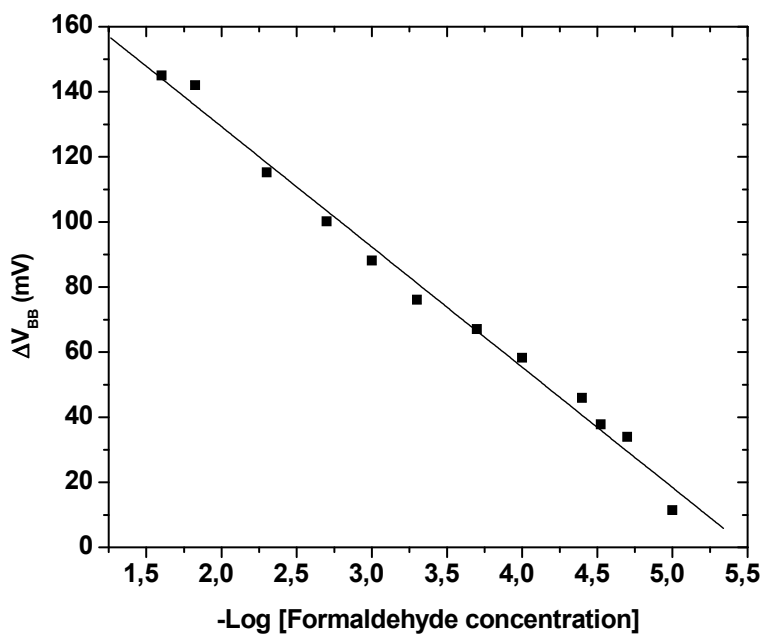

Fig. 8. Response of bio-functionalized $\mathrm{Si} / \mathrm{SiO}_{2} / \mathrm{Si}_{3} \mathrm{~N}_{4}$ structure for FA (in logarithms of the molar concentration) in the tested solution

To construct FA-selective conductometric biosensor, the novel method was proposed using thin-film interdigitated gold planar electrodes and $\mathrm{FdDH}$ (commercial bacterial or recombinant yeast $\mathrm{rFdDH}$ ) co-immobilized with cofactor(s) in the presence of DEAEDextran (Korpan et al., 2010).

DEAE-Dextran prevents active leakage of cofactors out of the bioselective layer and allows for the reuse of the biosensor without the regeneration of the cofactor(s), since its(their) concentration(s) in the layer is (are) high, constituting $100 \mathrm{mM}$ and $20 \mathrm{mM}$ for NAD ${ }^{+}$and GSH, respectively.

The working signals obtained for the conductometric biosensors based on $\mathrm{rFdDH}$ and $\mathrm{FdDH}$, allow to assume that the apparent value of $\mathrm{pH}$ shift in the bioselective membrane does not exceed 0.4 units of $\mathrm{pH}$. Due to the $\mathrm{pH}$ of the working solution (exactly, 8.7) used for measurements and some processes of protons masking, the steady-state value of protons inside the selective membrane can be estimated as $10^{-7} \mathrm{M}$. This means that during one assay the concentration of cofactor $\left(\mathrm{NAD}^{+}\right)$consumed during FA transformation is about 6 orders lower in comparison with the concentration of $\mathrm{NAD}^{+}\left(10^{-1} \mathrm{M}\right)$ immobilized on the transducer surface. Even taking into account that $90 \%$ of $\mathrm{NAD}^{+}$could leak out of the membrane due to the washing procedures, and assuming that transformation efficiency of 
the analyte is approx. $1 \%$, the remaining effective level of $\mathrm{NAD}^{+}$has to be quite enough to perform up to 1.000 measurements using the same transducer. These calculations correlate well with the data obtained experimentally by tests performed on the developed biosensors over a 3 month period: more than 200 measurements on the same transducer have been made without any loss of the sensor signal and sensitivity. At the same time, most of the previously reported FdDH-based sensors (Vianello et al., 1996; Kataky et al., 2002) are based on the usage of covalently bounded $\mathrm{NAD}^{+}$, which essentially decreases its availability and effectiveness for enzyme-substrate interactions.

It was studied the dependence of the developed $\mathrm{rFdDH}$-based conductometric biosensor response on FA concentrations (Table 9). It has been shown (Fig. 9), that the conductometric biosensor is highly selective and even specific to FA, the basic substrate of FdDH. Other compounds, in particularly ethanol and ethanol, caused the significant changes in responces of the proposed conductometric biosensor. However, the usage of methanol and ethanol mixtures with FA leads to slight alteration of $\mathrm{rFdDH}$-based conductometric sensor response values toward FA.

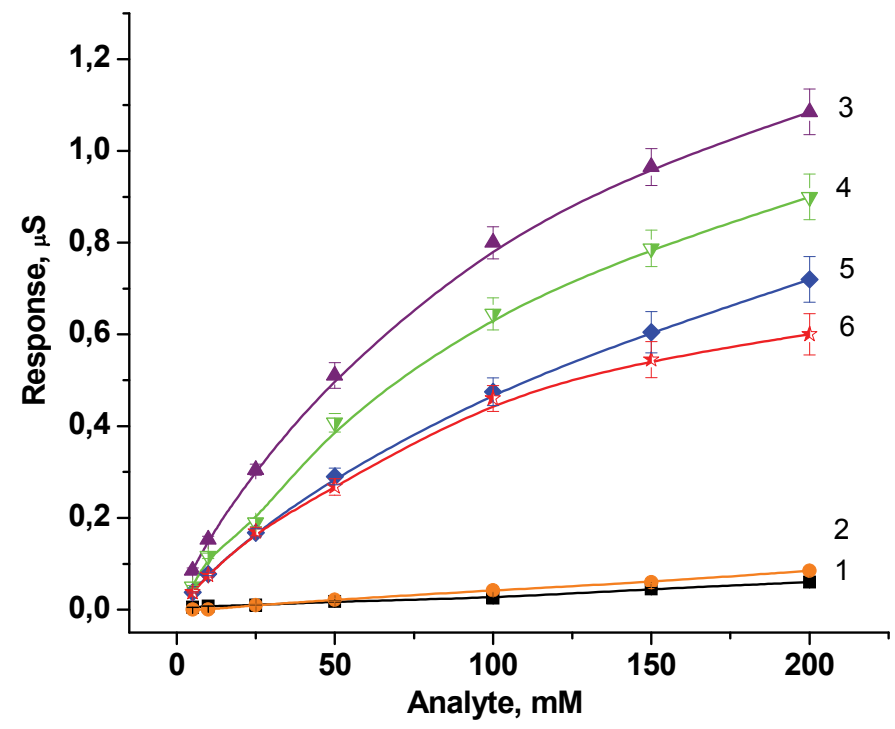

Fig. 9. Selectivity of the developed $\mathrm{rFdDH}$-based biosensor to different substrates: 1 methanol, 2 - ethanol, 3 - formaldehyde, 4 - equimolar mixture of FA and methanol, 5 equimolar mixture of FA and ethanol, 6 - methanol, ethanol and FA. The measurements were performed in $10 \mathrm{mM}$ borate buffer, $\mathrm{pH} 8.7$

\subsection{FdDH- and cells-based amperometric biosensors}

The recombinant yeast cells Tf 11-6 H. polymorpha and FdDH isolated from these cells were used as biorecognition elements of amperometric biosensors. In the physiological electrontransfer pathway, electrons are transferred from FA via intermediate G-SH to the active centre of FdDH with the simultaneous reduction of $\mathrm{NAD}^{+}$to NADH. To design an electrontransfer pathway for the immobilised FdDH as a bioselective element of the sensor, the 
enzymatically generated NADH has to be re-oxidised additionally at the electrode surface using a suitable redox mediator (Fig. 10).

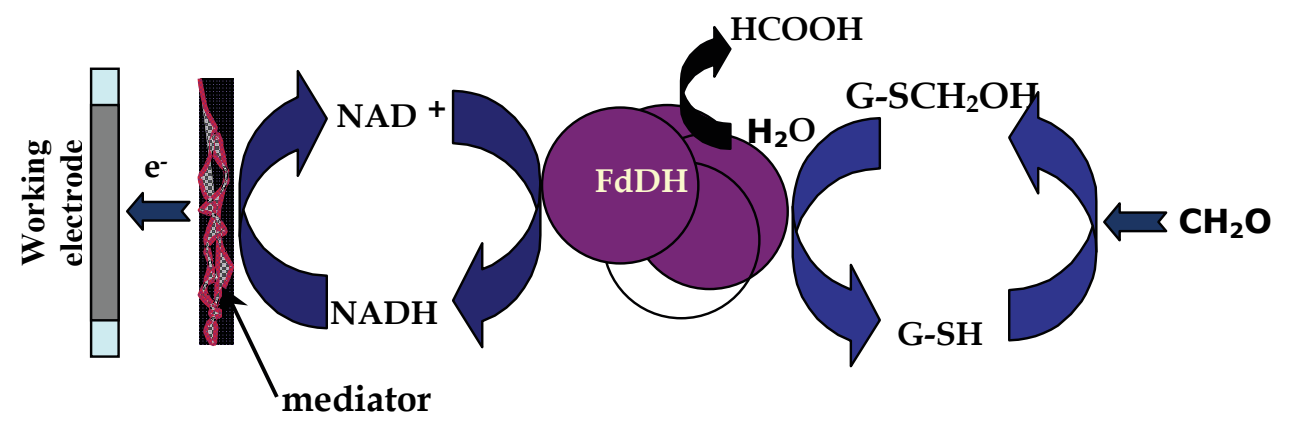

Fig. 10. Schematic representation of the electron pathway for FA detection by FdDH-based amperometric biosensor

The best mediators for enzyme biosensors were shown to be positively charged cathodic electrodeposition paints modified with Os-bis-N,N-(2,2'-bipyridil)-dichloride $\left(\left[\mathrm{Os}(\mathrm{bpy})_{2} \mathrm{Cl}_{2}\right]\right.$ ) complexes (Ngounou et al., 2004). Among five tested Os-containing redox polymers of different chemical structures and properties, complex 1CPOs of osmiummodified poly(4-vinylpyridine) with molecular mass of $60 \mathrm{kDa}$ and containing diaminopropyl groups was selected as the most suitable redox polymer. At the same time, the polymer layer served as a matrix for keeping the negatively charged low-molecular cofactors, GSH and $\mathrm{NAD}^{+}$, within the bioactive layer. In cells-based biosensors phenazine methosulfate (free-diffusing redox mediator, PMS) exhibited the best electron transfer characteristics (Demkiv et al., 2008; Gayda et al., 2008).

For construction of the envisaged FA biosensor, it was proposed a sophisticated sensor architecture with the aim of securely fixing all sensor components in a bioactive layer onto the transducer surface. Especially, the sensor architecture was designed to prevent any leakage of the low-molecular and free-diffusing cofactors of the enzyme, thus enabling FA determination without the addition of the cofactors to the analyte solution [(Demkiv et al., 2008; Gayda et al., 2008). In the optimized biosensor's construction, platinised graphite electrode, with $3.05 \mathrm{~mm}$ diameter, was used as a transducer and $\left[\mathrm{O}_{\mathrm{s}}(\mathrm{Me} 2 \mathrm{bpy})_{2} \mathrm{Cl}_{2}\right]$-modified positively charged cathodic paint 1CPOs was found to be the best redox mediator, as well as a good matrix for enzyme or cells electrodeposition and for holding enzyme's co-factors, GSH and NAD, in a bioactive layer. Covering of the bio-layer by a negatively charged Nafion membrane additionally prevented the leakage of cofactors and enhanced sensor's stability.

Bioanalytical characteristics of the constructed biosensors were studied in detail: kinetics, dynamic and linear range, selectivity, and effect of temperature on sensor output (Table 9). For the enzyme-based biosensor, the maximum current value was $250 \pm 5.25 \mu \mathrm{A}$ and the

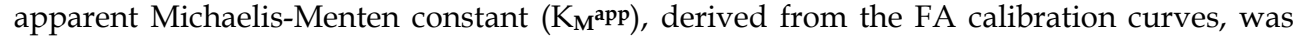
$120 \pm 5.3 \mathrm{mM}$ with a linear detection range for FA up to $20 \mathrm{mM}$. For the cell-based biosensor, the maximum current value was $1.07 \pm 0.04 \mu \mathrm{A}$, and $\mathrm{K}_{\mathbf{M}^{\text {app }}}$ was $20.1 \pm 1 \mathrm{mM}$ with a linear detection range for FA up to $8 \mathrm{mM}$. The optimal $\mathrm{pH}$-value for the developed biosensors was in the range of 7.6 to 8.3 with an optimal temperature between $45-50{ }^{\circ} \mathrm{C}$ (Gayda et al., 2008), due 
to a higher thermostability of the enzyme used, and thermotolerance of recombinant yeast cells. The bioanalytical properties of the developed biosensors were evaluated with the specific aim of improving the long-term operational stability of the sensor. The novel biosensors demonstrated a good sensitivity, high selectivity to FA and a good stability (Fig. 11-13).

A typical response of the developed 1CPOs-NAD+-FdDH-modified electrodes towards FA is shown in Fig. 11 A. As can be seen from Fig. 11 B, $K_{M}$ values for FA, obtained by using intact- and permeabilized recombinant cells-based biosensors, are similar, but I max value for the intact-cell-based sensor is 2-fold higher than for the sensor with permeabilized cells.

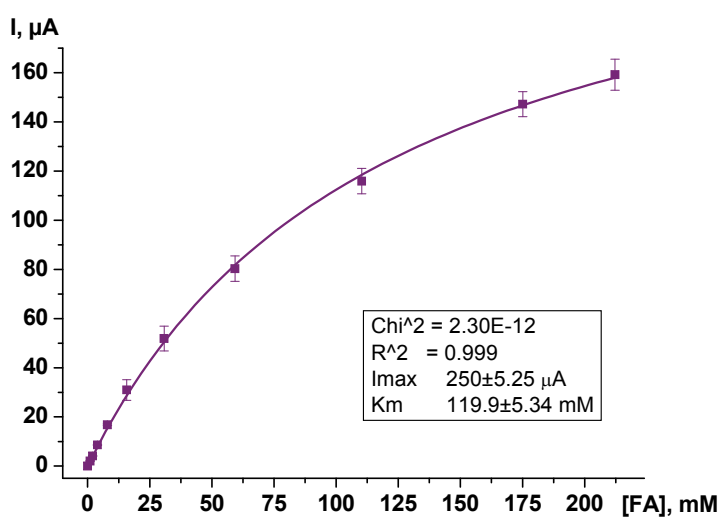

(A)

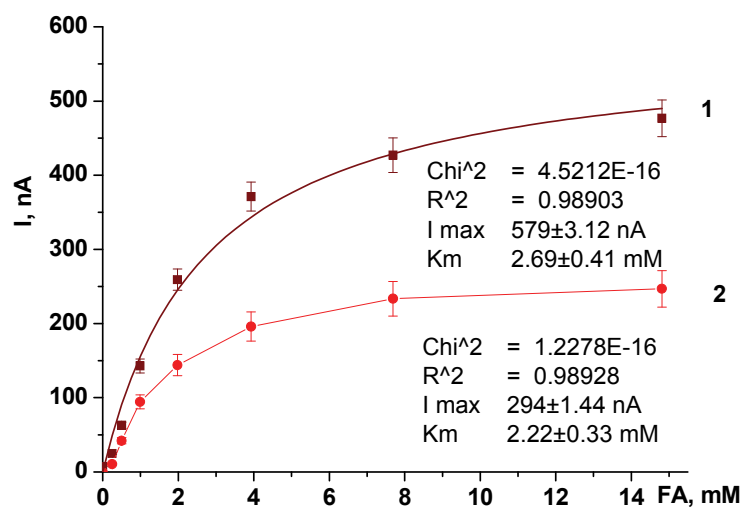

(B)

Fig. 11. Chronoamperometric determination of FA, using A - 1CPOs-NAD+-FdDH-GSHNafion -based biosensor; B - Cells-Tf 11-6-NAD+-GSH-Nafion-modified graphite electrode (1) and permCells-Tf 11-6-NAD+-GSH-Nafion-modified graphite electrode (2). Potential 0 $\mathrm{mV}$ against $\mathrm{Ag} / \mathrm{AgCl} / 3 \mathrm{M} \mathrm{KCl}$ in phosphate buffer, $\mathrm{pH}$ 8.0, with $0.2 \mathrm{mM}$ PMS 


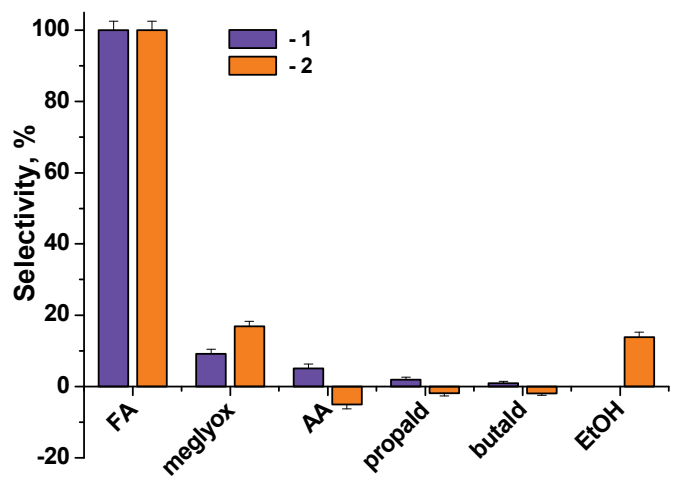

Fig. 12. Selectivity of the developed amperometric enzyme-(1) and cell-based (2) biosensors to different substrates: meglyox - methylglyoxal; AA - acetaldehyde; propald propionaldehyde; butald - butyraldehyde; $\mathrm{EtOH}$ - ethanol

Another amperometric biosensor, developed (Nikitina et al., 2007) in a co-operation with the scientific group headed by Prof. E. Czoregi (University of Lund, Sweden), was a bilayer bienzyme sensor based on diaphorase and $\mathrm{FdDH}$, together with $\left[\mathrm{Os}\left(4,4^{\prime}-\right.\right.$ dimethylbipyridine) $\left.{ }_{2} \mathrm{Cl}\right] /(\mathrm{PVP}-\mathrm{Os})$. The sensor's architecture was comprised of a first layer containing diaphorase from Bacillus stearothermophilus, cross-linked with the PVP-Os redox polymer. On the top of this layer, a second layer was formed by additional cross-linking of FdDH with poly(ethylene glycol)(400)diglycidyl ether. The sensor architecture was optimised with respect to efficient electron transfer and stability of the enzyme(s). The developed bi-enzyme FdDH-DPH-PVP-Os-modified electrode displayed the best characteristics for FA detection in flow injection mode of a sample.

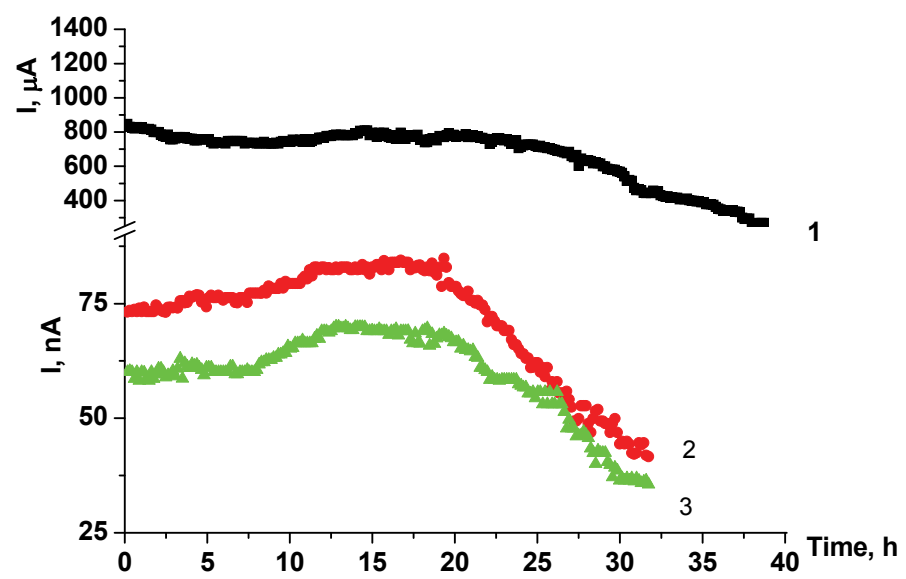

Fig. 13. Operational stability of the optimised FA biosensors: enzymatic-based (1), cellbased (2) and permeabilized cell-based (3). Bioelectrodes were tested in an automatic sequential injection analyser. Flow-rate $5 \mathrm{ml} \mathrm{min}^{-1}$; sample injection every $4 \mathrm{~min}$. Potential 0 $\mathrm{mV}$ against $\mathrm{Ag} / \mathrm{AgCl} / 3 \mathrm{M} \mathrm{KCl}$ in phosphate buffer, $\mathrm{pH}$ 8.0, with $0.2 \mathrm{mM}$ PMS 
The basic bioanalytical characteristics of the bi-enzyme biosensor, polarized at $+180 \mathrm{mV}$ vs. NHE, are presented in Table 9 and Fig. 14. The biosensor-FA reaction obeys typical Michaelis-Menten kinetics. The detection limit was found to be $32 \mu \mathrm{M}$, while the dynamic range was shown to be linear between 0.05 and $0.5 \mathrm{mM} \mathrm{FA}$. The slope of the calibration curve (sensitivity) and the linear correlation coefficient were $22 \mathrm{Am}^{-2} \mathrm{M}-1$ and 0.998 , respectively. The stability of the $\mathrm{FdDH}$ immobilized on the electrode was also evaluated. When the biosensors were stored at $4{ }^{\circ} \mathrm{C}$ in phosphate buffer, $\mathrm{pH} 7.5$, the response was linear with a loss of $50 \%$ of the activity after $24 \mathrm{~h}$. Dry storage of the immobilized electrode at the same temperature resulted in the complete inactivation of the immobilized enzyme.

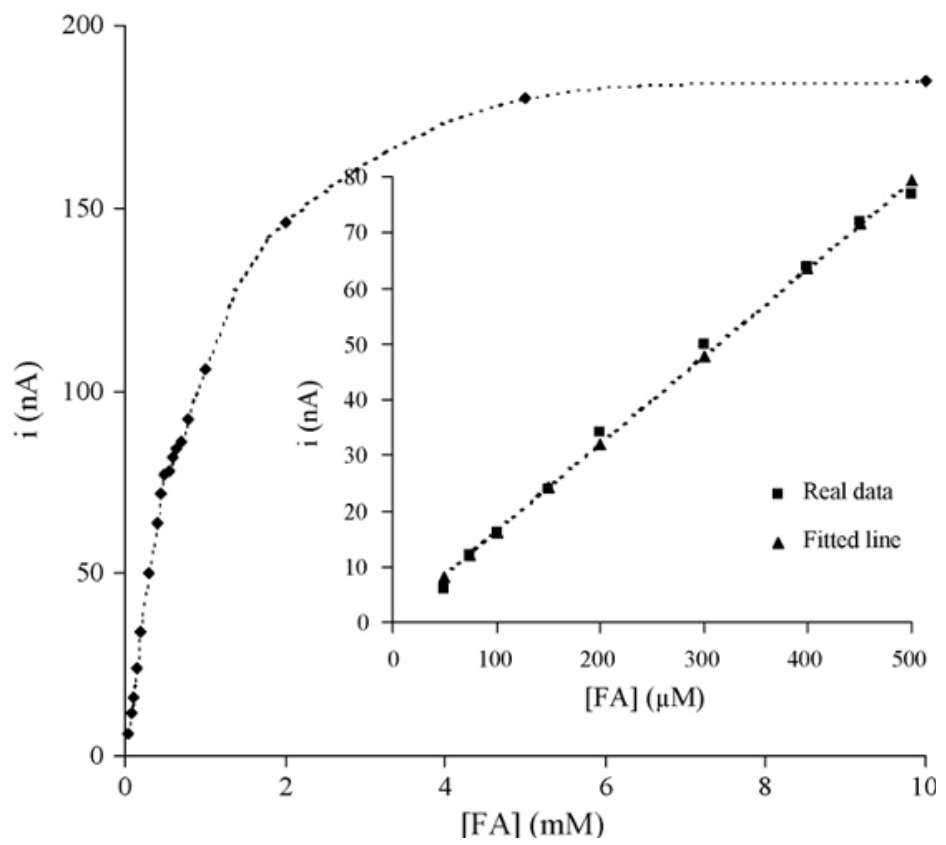

Fig. 14. Calibration curve of the FdDH-DPH-PVP-Os-modified electrode (0.5 mM NAD+; $0.25 \mathrm{mM}$ GSH; $0.1 \mathrm{M}$ phosphate buffer, $\mathrm{pH} 7.5 ; E \mathrm{appl}=160 \mathrm{mV} ; 0.4 \mathrm{ml} / \mathrm{min}$ flow rate)

\subsection{The comparison of the developed FA-selective biosensors}

Tables 9 and 10 represent a brief summary of the published results on the developed microbial and enzyme-based FA biosensors with differend types of signal detection. The amperometric biosensors, enzyme- and cell-based, work at a very low applied potential, compared with other known biosensors (zero or 160 vs. 340,610 or $560 \mathrm{mV}$ ), thus the possible interferences (e.g., methanol, ethanol, acetic acid) should be considerably reduced. Different approaches were used for biosensor monitoring FA-dependent cell response: 1) analysis of their oxygen consumption rate by using a Clark electrode; 2) assay of oxidation of redox mediator at a screen-printed platinum electrode covered by cells entrapped in Caalginate gel (Khlupova et al., 2007). 
The dynamic ranges of all described biosensors were of micromolar values. As can be seen from Tables 9 and 10, AOX- and FdDH-based biosensors, constructed for potentiometric and conductometric signals registration, have high storage stability.

\begin{tabular}{|c|c|c|c|c|c|c|}
\hline \multirow{2}{*}{ Characteristics } & \multicolumn{4}{|c|}{ FdDH-based } & \multicolumn{2}{c|}{ AOX-based } \\
\cline { 2 - 7 } & Bi-enzyme & \multicolumn{3}{|c|}{ Mono-enzyme } & $\begin{array}{c}\text { Mono- } \\
\text { enzyme }\end{array}$ & Bi-enzyme \\
\hline $\begin{array}{c}\text { Type of signal } \\
\text { detection }\end{array}$ & \multicolumn{2}{|c|}{ Amperometric } & $\begin{array}{c}\text { Capaci- } \\
\text { tance }\end{array}$ & $\begin{array}{c}\text { Conducto- } \\
\text { metric }\end{array}$ & $\begin{array}{c}\text { Potentio- } \\
\text { metric }\end{array}$ & $\begin{array}{c}\text { Ampero- } \\
\text { metric }\end{array}$ \\
\hline $\begin{array}{c}\text { Detection limit, } \\
\mathrm{mM}\end{array}$ & 0.032 & 0.003 & 0.01 & 10 & - & 0.024 \\
\hline $\begin{array}{c}\text { Linear range, } \\
\mathrm{mM}\end{array}$ & $0.05-0.5$ & up to 20.0 & $0.01-25$ & $10-200$ & $5-200$ & 4 \\
\hline $\mathrm{I}_{\mathrm{max}, \mu \mathrm{A}}$ & 0.18 & 250 & - & - & - & 0.8 \\
\hline $\begin{array}{c}\text { Sensitivity, } \\
{ }^{\mathrm{A}} \cdot \mathrm{m}^{-2} \cdot \mathrm{M}-1\end{array}$ & $22^{*}$ & $358^{*}$ & $\begin{array}{c}31 \mathrm{mV} / \\
\text { decade }\end{array}$ & - & $\begin{array}{c}50 \mathrm{mV} / \\
\text { decade }\end{array}$ & $114^{*}$ \\
\hline $\begin{array}{c}\text { Storage stability, } \\
\text { days }\end{array}$ & 1 & 3 & - & 140 & 120 & 14 \\
\hline $\begin{array}{c}\text { Reference } \\
\text { Nikitina }\end{array}$ & $\begin{array}{c}\text { Demkiv } \\
\text { et al., } \\
\text { et al., } 2007\end{array}$ & $\begin{array}{c}\text { Ben Ali } \\
\text { et al., } 2007\end{array}$ & $\begin{array}{c}\text { Korpan } \\
\text { et al., } 2010\end{array}$ & $\begin{array}{c}\text { Korpan } \\
\text { et al., } 2000\end{array}$ & $\begin{array}{c}\text { Smutok } \\
\text { et al., } 2006\end{array}$ \\
\hline
\end{tabular}

Table 9. Bioanalytical characteristics of enzyme-based biosensors

\begin{tabular}{|c|c|c|c|c|c|c|c|}
\hline \multirow{3}{*}{$\begin{array}{c}\text { Parameter } \\
\begin{array}{l}\text { pplied potential } \\
(\mathrm{mV})\end{array}\end{array}$} & \multicolumn{4}{|c|}{ Cells H. polymorpha C-105 } & \multicolumn{3}{|c|}{ Cells H. polymorpha Tf 11-6 } \\
\hline & \multicolumn{2}{|c|}{ Intact } & \multicolumn{2}{|c|}{ Permeabilized } & \multicolumn{2}{|c|}{ Intact } & \multirow{2}{*}{\begin{tabular}{|c}
$\begin{array}{r}\text { Permea- } \\
\text { bilized }\end{array}$ \\
0
\end{tabular}} \\
\hline & -600 & +200 & -600 & - & +200 & 0 & \\
\hline Mediator & - & DCIP & - & - & CP58-Os & PMS & PMS \\
\hline Registration type & $\begin{array}{c}\text { Clark } \\
\text { electrode }\end{array}$ & $\begin{array}{c}\text { Ampe- } \\
\text { rometric }\end{array}$ & $\begin{array}{c}\text { Clark } \\
\text { electrode }\end{array}$ & $\begin{array}{l}\text { Potenti- } \\
\text { ometric }\end{array}$ & \multicolumn{3}{|c|}{ Amperometric } \\
\hline $\begin{array}{l}\text { Linear dynamic } \\
\text { range, } \\
\mathrm{mM}\end{array}$ & up to 3.0 & $1.0-7.0$ & $0.3-4.0$ & $5-50$ & $0.5-6.0$ & $0.25-8.0$ & $1.0-2.5$ \\
\hline $\begin{array}{l}\text { Detection limit, } \\
\mathrm{mM}\end{array}$ & 0.6 & 0.74 & 0.27 & 3.5 & 0.003 & 0.11 & 0.5 \\
\hline Sensitivity & *1.15 & $\begin{array}{c}8.62 \\
\mathrm{nA} \cdot \mathrm{mM}^{-1} \\
\end{array}$ & ${ }^{*} 0.44$ & - & $\begin{array}{c}2.65 \\
\mu \mathrm{A} \mathrm{mM}^{-1}\end{array}$ & $\begin{array}{c}37.5 \\
\mathrm{nA} \cdot \mathrm{mM}^{-1}\end{array}$ & - \\
\hline Storage stability & - & - & - & 30 & 16 & 20 & 7 \\
\hline Reference & \multicolumn{3}{|c|}{ Khlupova et al., 2007} & \begin{tabular}{|} 
Korpan \\
et al., 2000
\end{tabular} & \multicolumn{3}{|c|}{$\begin{array}{l}\text { Demkiv et al., 2008, } \\
\text { Paryzhak et al., } 2008\end{array}$} \\
\hline
\end{tabular}

* Oxygen consumption rate per $1 \mathrm{mM}$ of FA $\left(\mu \mathrm{M} \mathrm{O} \mathrm{S}^{-1} \cdot \mathrm{mM}^{-1}\right)$

Table 10. Comparison of microbial (yeast cells-based) FA-sensitive biosensors. DCIP - 2,6dichlorophenolindophenol; PMS - phenazine methosulfate 
Such excellent stability is intrinsic for cell-based sensors, too. Both amperometric and capacitance biosensors, AOX-, FdDH- and cells Tf 11-6 based, are very sensitive to low FA concentrations (Demkiv et al., 2008, Smutok et al., 2006, Ben Ali et al., 2007). FdDH-based biosensors have very important property for FA analysis in real samples - high selectivity to FA, compared with AOX-and cells-based sensors (Gayda et al., 2008).

\subsection{Application of biosensors for FA-monitoring in real samples}

The purified $\mathrm{FdDH}$, as well as recombinant $H$. polymorpha cells overproducing this enzyme were used for construction of enzyme-based and microbial electrochemical biosensors selective to FA. The reliability of the developed analytical approaches was tested on real samples of wastewaters, pharmaceuticals, and FA-containing industrial products. As we can see from table 11, the proposed methods, approved on the real FA-containing samples, are well correlated with the results of the known chemical methods and novel FdDH-based analytical kit "Formatest" (Demkiv et al., 2009).

The constructed amperometric biosensors revealed a high selectivity to FA (100\%) and a very low cross-sensitivity to other structurally similar substances: butyraldehyde $(0,93 \%)$, propionaldehyde $(1,89 \%)$, acetaldehyde $(5,1 \%)$, methylglyoxal $(9,12 \%)$ (Paryzhak et al., 2007). These sensors were applied for FA testing in some industrial goods: Formidron, Descoton forte, formalin and rabbit vaccine against viral hemorrhage. A good correlation was observed between the data of FA testing (Table 11) by the amperometric biosenor's approaches (FdDH and cells-based), proposed enzymatic method "Formatest" and standard chemical methods.

\begin{tabular}{|c|c|c|c|c|c|c|c|c|}
\hline \multirow{4}{*}{$\begin{array}{l}\text { Sample/ } \\
\text { Method }\end{array}$} & \multicolumn{3}{|c|}{ Chemical methods } & \multicolumn{5}{|c|}{ FdDH-based methods } \\
\hline & \multirow{3}{*}{ MBTH } & \multirow{3}{*}{$\begin{array}{l}\text { Chromo- } \\
\text { tropic } \\
\text { acid }\end{array}$} & \multirow{3}{*}{ Purpald } & \multirow{3}{*}{$\begin{array}{c}\text { Forma- } \\
\text { test }\end{array}$} & \multicolumn{4}{|c|}{ Biosensors } \\
\hline & & & & & \multicolumn{3}{|c|}{ Amperometric } & Conducto- \\
\hline & & & & & FdDH & $\mathrm{FdDH}^{*}$ & Cells & FdDH \\
\hline Formidron & $\begin{array}{c}1.64 \pm \\
0.61\end{array}$ & $1.48 \pm 0.26$ & $\begin{array}{c}1.20 \pm \\
0.20\end{array}$ & $\begin{array}{c}1.53 \pm \\
0.31\end{array}$ & $\begin{array}{c}1.57 \pm \\
0.13\end{array}$ & $\begin{array}{c}1.50 \pm \\
0.60\end{array}$ & $\begin{array}{c}1.48 \pm \\
0.06\end{array}$ & $1.69 \pm 0.13$ \\
\hline $\begin{array}{l}\text { Descoton } \\
\text { forte }\end{array}$ & $\begin{array}{c}3.57 \pm \\
0.30\end{array}$ & $3.59 \pm 0.44$ & $\begin{array}{c}3.30 \pm \\
0.30\end{array}$ & $\begin{array}{c}3.25 \pm \\
0.80\end{array}$ & $\begin{array}{c}3.61 \pm \\
0.13\end{array}$ & $\begin{array}{c}3.50 \pm \\
0.30\end{array}$ & $\begin{array}{c}3.29 \pm \\
0.12\end{array}$ & $14.10 \pm 0.80$ \\
\hline Formalin & $\begin{array}{c}12.6 \pm \\
0.73 \\
\end{array}$ & $14.0 \pm 0.81$ & $\begin{array}{c}12.9 \pm \\
0.70 \\
\end{array}$ & $\begin{array}{c}13.5 \pm \\
0.54 \\
\end{array}$ & $\begin{array}{c}13.6 \pm \\
0.6\end{array}$ & $\begin{array}{c}13.6 \pm \\
0.6\end{array}$ & $\begin{array}{c}13.8 \pm \\
0.54 \\
\end{array}$ & $12.99 \pm 0.18$ \\
\hline $\begin{array}{c}\text { Rabbit } \\
\text { vaccine } \\
\text { against viral } \\
\text { hemorrhage }\end{array}$ & $\begin{array}{c}0.038 \pm \\
0.003\end{array}$ & $0.029 \pm 0.005$ & $\begin{array}{c}0.043 \pm \\
0.005\end{array}$ & $\begin{array}{c}0.042 \pm \\
0.004\end{array}$ & $\begin{array}{c}0.041 \pm \\
0.005\end{array}$ & - & $\begin{array}{c}0.042 \pm \\
0.002\end{array}$ & - \\
\hline Reference & \multicolumn{4}{|c|}{$\begin{array}{c}\text { Demkiv, et al., } 2008 \text {, Demkiv, et al., } \\
2009\end{array}$} & \multicolumn{2}{|c|}{$\begin{array}{l}\text { Demkiv, } \\
\text { et al., } 2008\end{array}$} & & $\begin{array}{l}\text { Korpan } \\
\text { et al., } 2010\end{array}$ \\
\hline
\end{tabular}

Table 11. FA content in molar concentration in real samples, $\mathrm{M} \pm \mathrm{m}$, determined by different methods: chemical (MBTH, Chromotropic acid); enzymatic method "Formatest", FdDHbased, and biosensor approaches (FdDH- and recombinant cells Tf 11-6 -based). *FdDH enzyme was Integrated in analyzer "OLGA" with Flow Injection mode. 
The conductometric sensors, FdDH- and rFdDH-based (Korpan et al., 2010), were evaluated in determining the FA content in real samples of the industrial product Formalin and two pharmaceuticals, the antimicrobial agent Descoton forte and antiperspirant Formidron, and the results of these tests are summarized in Table 11. As for the amperometric rFdDH-based sensor, the maximal interfering effect for the proposed conductometric biosensors was observed for Descoton, less for Formidron, and the smallest for Formalin. The results obtained for Descoton are due to the presence in this preparation of high quantities of glutaric aldehyde, which consequently changing substantially the mechanical and catalytic properties of the bioselective layer, since it can cause cross-linking reactions. For all investigated samples, a good correlation was observed between the conductometric sensor values and enzymatic or chemical methods. These analytical data confirm the possibility to exploit the developed biosensors for FA assay at least in real samples of non-complicated compositions such as pharmaceuticals, potable water and wastewater.

\section{FA removal from indoor air}

For removal of FA from indoor air a number of methods have been proposed. Physical adsorption of FA with activated carbon (Boonamnuayvitaya et al., 2005; Tseng et al., 2003), by various fractions of karamatsu bark (Takano et al., 2008) and by zeolites (Cazorla \& Grutzeck, 2006) was shown to demonstrate good to high results, but simple adsorption cannot provide a radical solution to the problem, since FA does not decompose, but is only transferred from one phase (air) to another (solid). Efforts, attempting to carry out the physical decomposition of FA, with the help of photo-catalytic, negative ions and ozone air cleaners resulted in the elimination of only up to $50 \% \mathrm{FA}$, and failed to reach acceptable FA concentrations as specified by WHO guidelines (0.08 ppm) (Tseng et al, 2003). Chemical decomposition of FA by composite silica particles functionalized with amine groups and platinum nanoparticles demonstrated a very high capacity for removing FA (Lee et al., 2008), but this process is expensive. Another approach to the chemical elimination of FA from air was developed in the work of Sekine, where manganese dioxide was shown to be effective in the oxidation of FA (Sekine, 2002; Tian \& He, 2009). Combustion of a formaldehyde-methanol mixture in an air stream on $\mathrm{Mn} / \mathrm{Al}_{2} \mathrm{O}_{3}$ and $\mathrm{Pd}-\mathrm{Mn} / \mathrm{Al}_{2} \mathrm{O}_{3}$ catalysts was shown to result in a total conversion of organic compounds (Álvarez-Galván, et al., 2004). Some chemical approachs to FA decomposition are highly effective, but solid wastes still remain as a by-product of these processes, in most cases containing harmful toxic components that cause subsequent utilization problems.

FA removal from air using biological decomposition is still not well developed. Theoretically, biofilters containing natural microorganisms capable of decomposing FA can be used for this purpose. Several biofilters and biotrickling filters were tested for the treatment of a mixture of formaldehyde and methanol (Prado et al., 2004, 2006), and a maximum FA elimination capacity of $180 \mathrm{~g} \mathrm{~m}^{-3} \mathrm{~h}^{-1}\left(3 \mu\right.$ moles g-1 $\left.\mathrm{h}^{-1}\right)$ was reached.

Recently, enzyme-based approaches have been proposed for FA bioremediation of indoor air. To this aim, continuous flow bioreactors based on the immobilized FA-oxidizing enzyme AOX or mutant yeast cells overproducing this enzyme were constructed (Sigawi et al., 2010).

AOX isolated from mutant $H$. polymorpha C-105 cells was immobilized in calcium alginate beads and applied for the bioconversion of airborne FA. The AOX preparation had a specific activity in the range of 6-8 $\mathrm{U} \cdot \mathrm{mg}^{-1}$ protein and was shown to preserve $85-90 \%$ of the initial 
activity after incorporation into the calcium alginate gel. This activity was proven to remain unchanged for up to seven months upon storage of the immobilized enzyme at $4{ }^{\circ} \mathrm{C}$.

A fluidized bed bioreactor (FBBR) based on glass columns was filled with gel beads containing immobilized AOX and suspended in phosphate buffer-saline. Columns filled with gel alone were used as control. FA-containing air was bubbled through the columns from the bottom to the top (Fig. 15) as described previously in Sigawi et al, 2010. The results showed that in the case of the $20 \mathrm{ml}$ reactors, the outlet FA concentration was less than $0.03 \mathrm{ppm}$, i.e. ten-fold less than the threshold limit value (TVL), and the $750 \mathrm{ml}$ reactor outlet air contained no FA at all. The FA concentration in the gas phase at the outlet from the control columns without the enzyme was essentially higher (0.09-0.1 ppm) than the test columns, but also relatively low compared to the input level, evidently due to FA dissolution in the liquid phase of the column and possibly also due to adsorption by the gel. The FA concentration in the bioreactor liquid phase of the test column was ca. 1-2 mM (Fig. 16), and in the control experiment ranged from 6 $\mathrm{mM}$ (750 $\mathrm{ml}$ reactor, Fig. 16) to $20 \mathrm{mM}$ (20 $\mathrm{ml}$ reactor).

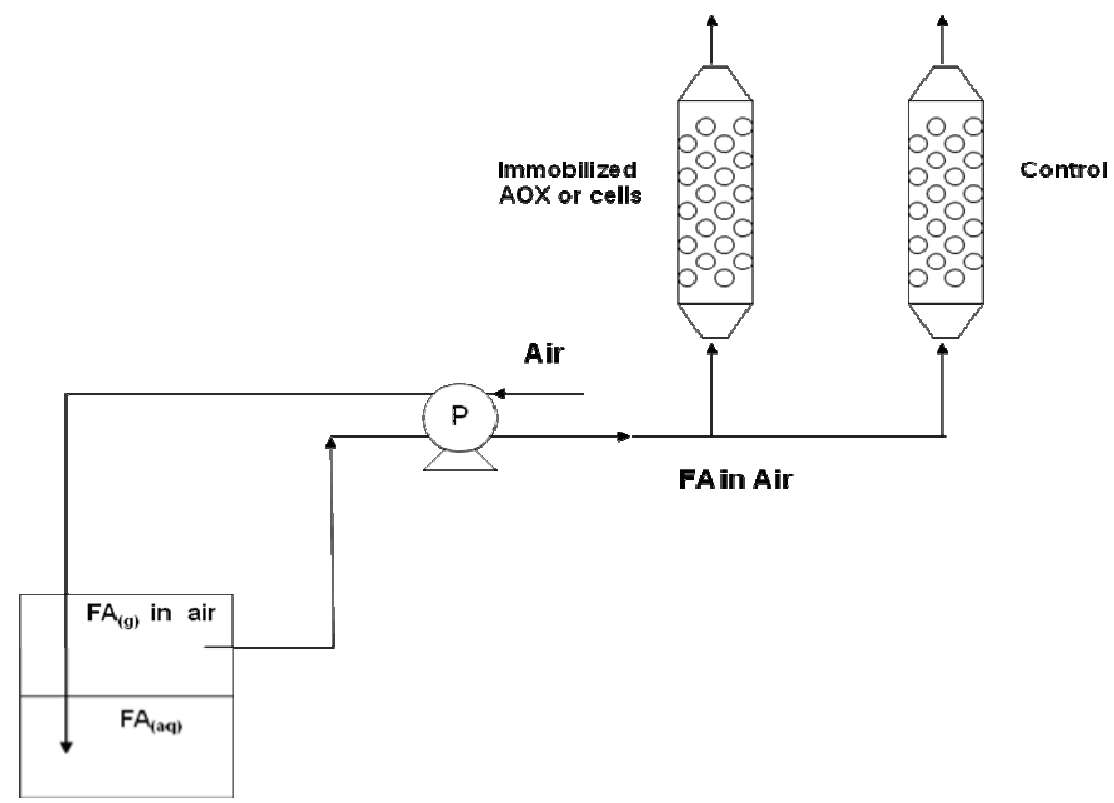

Fig. 15. Scheme for oxidation of airborne FA by AOX immobilized in calcium alginate or cells in a continuous FBBR. 1.5 or $38 \mathrm{~g}$ gel beads containing AOX with $6.6 \mathrm{U} \cdot \mathrm{g}^{-1}$ of the gel in 20 or $750 \mathrm{ml} 0.05 \mathrm{M}$ PBS, pH 7.5, were applied onto a $1 \times 30 \mathrm{~cm}$ or $10 \times 10 \mathrm{~cm}$ column, which was connected at the bottom to the source of FA in air at $25^{\circ} \mathrm{C}$. The $0.3-18.5 \mathrm{ppm}$ FA concentrations in air were generated by bubbling 7-152 $\mathrm{ml} \cdot \mathrm{min}^{-1}$ airflow through an aqueous FA solution at concentrations of 2.7-100 mM. The control columns contained gel beads without immobilized material. The FA concentrations were tested for about three weeks in the outlet gas phase with a Formaldehyde Gas Detector (Model FP-40 Riken Keiki, Japan) and also in the aqueous column phase by a standard photometric method using a reaction with $1 \%$ chromotropic acid (Sawicki et al., 1961), as well as by the amperometric FdDHbased biosensor (Sigawi, 2010). 
The proposed method for FA removal from indoor air by the enzyme AOX entrapped in alginate gel provides not only an effective bioconversion of FA in the gas phase, but also a safe FA level in the liquid phase of the continuous FBBR. After termination of the process the contents of the bioreactor can be used as organic fertilizer, since the gel beads together with the liquid phase are free of hazardous components. The entire process can therefore be considered as entirely environmentally friendly. It can be concluded that the proposed bioreactor is suitable for treating air containing various FA concentrations.

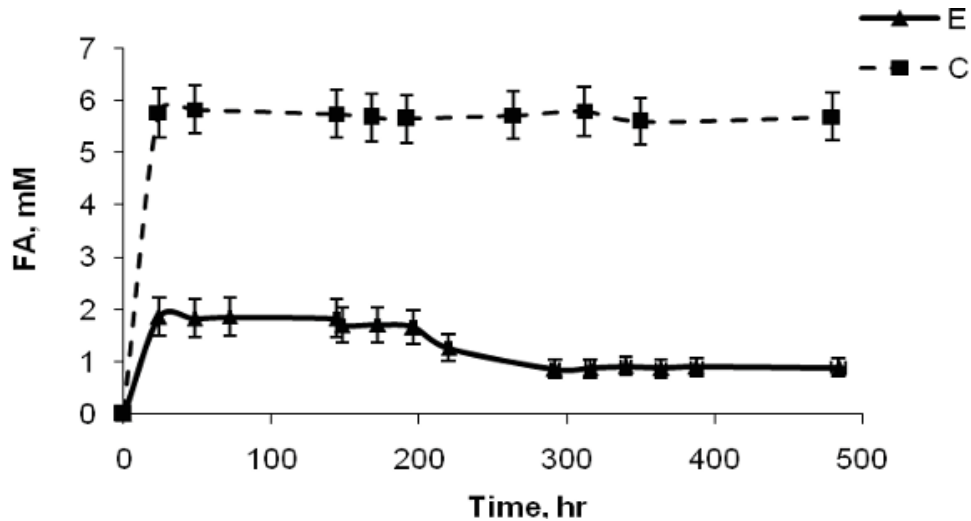

Fig. 16. FA concentration in the aqueous phase of the continuous FBBR upon oxidation of FA in the air by AOX immobilized in 1.5\% calcium alginate gel (E). Air flow was $152 \mathrm{ml} \cdot \mathrm{min}^{-}$ 1 , initial FA concentration in air was $18 \mathrm{ppm}$. The air was bubbled through a 10x10 cm column with $38 \mathrm{~g}$ gel beads, containing AOX with $6.6 \mathrm{U} \cdot \mathrm{g}^{-1}$ of the gel. FA concentration in the aqueous phase was monitored by a standard photometric method using a reaction with chromotropic acid, as well as by the amperometric FdDH-based biosensor. In the control experiment $(\mathrm{C})$, calcium alginate gel alone was used.

\section{Conclusion}

Bioremediation of wastes polluted by formaldehyde (FA) and monitoring of this toxic compound in environment, commercial goods, potable water and food products is an important challenge for science and practiclal technology.

In this review, there are described enzymes- and cells-based approaches to monitor FA content in different sources (wastes, indoor air, industrial products, vaccines, and fish food). As the main analytical instrument selective to $\mathrm{FA}$, it has been used recombinant formaldehyde dehydrogenase $(\mathrm{FdDH})$ isolated from the gene-engineered strains of the thermotolerant methylotrophic yeast Hansenula polymorpha. The stable recombinant clones, containing 6-8 copies of the target FLD1 gene, were resistant to 15-20 mM FA in a medium due to over-synthesis of a homologous $\mathrm{NAD}^{+}$- and glutathione-dependent FdDH. A simple scheme for $\mathrm{FdDH}$ isolation and purification from the recombinant overproducers was developed, physico-chemical and catalytic properties of the purified enzyme were studied. The enzymatic method for FA assay, based on recombinant FdDH (with linear detection range from 0.01 to $0.05 \mathrm{mM}$ and detection limit $0.007 \mathrm{mM}$ ) and analytical kit "Formatest" 
were developed. In comparison with the known methods, the described procedure is rather simple: a method does not require transformation of FA into chemical adduct for the extraction of the target analyte from the tested sample. As compared to chemical methods, the analysis time is shorter and some dangerous operations (e.g. heating in strong acid) are not required. The developed method is approved on the FA-containing real samples, and data are well correlated with the results of the known chemical methods.

Another FA-oxidizing enzyme, alcohol oxidase (AOX) isolated from the mutant $H$. polymorpha (gcr1 catX), defective in glucose repression of AOX synthesis and avoid of catalase, was shown to be useful for enzymatic FA determination in wastes and industrial products. AOX in vivo oxidizes methanol, but in vitro has ability to catalyze the oxidation of other primary alcohols and hydrated form of FA $\left(\mathrm{HO}-\mathrm{CH}_{2}-\mathrm{OH}\right)$. For simultaneous assay of both FA and methanol in wastes, the specific chemico-enzymatic method was elaborated. AOX was also successfully used for FA assay in Gadoid fish products.

The purified preparations of $\mathrm{FdDH}$ and AOX, as well as H. polymorpha cells overproducing these enzymes were used for construction of enzyme-based and microbial electrochemical biosensors selective to FA. The reliability of the developed analytical approaches was tested on real samples of waste waters, pharmaceuticals, and FA-containing industrial products.

AOX and permeabilized mutant yeast cells of $H$. polymorpha (gcr1 catX) were shown to be used as the catalytic unit in cartridges for removing of formaldehyde from the indoor air. Experimental data confirm the possibility to exploit the developed bioreactors based on crude preparations of AOX or methylotrophic yeast cells for effective formaldehyde oxidation coupled with FdDH-based biosensor for accurate control of this process.

\section{Acknowledgements}

This work was financially supported by the Ministry of Science, Culture and Sport of the State of Israel (Grant 1236), by the Ministry of Science and Education of Ukraine (Grant M/157-2009) and by the National Academy of Sciences of Ukraine (Agreements № 16-2010, 6/1-2010 and 6/2-2010).

\section{References}

Achmann, S., Hermann, M. \& Hilbrig, F. (2008). Direct detection of formaldehyde in air by a novel $\mathrm{NAD}^{+}$and glutathione-independent formaldehyde dehydrogenase-based biosensor. Talanta, V. 75, №3, pp.786-791, ISSN: 0039-9140

Allais, J.J., Louktibi, A. \& Baratti, J. (1983). Oxidation of methanol by the yeast, Pichia pastoris, purification and properties of the formaldehyde dehydrohenase. Agric. Biol. Chem., V. 47, №7, pp.1509-1516, ISSN: 0002-1369

Alpeeva, I.S., Vilkanauskyte, A. \& Ngounou, B. (2005). Bi-enzyme alcohol biosensors based on genetically engineered alcohol oxidase and different peroxidases. Microchim. Acta., V. 152, pp. 21-27, ISSN: 0026-3672

Álvarez-Galván, M.C., Pawelec, B. \& de la Peña O'Shea (2004). Formaldehyde/methanol combustion on alumina-supported manganese-palladium oxide catalyst. Applied Catalysis B: Environmental, V.51, pp. 83-91, ISSN: 0926-3373 
Auerbach, C., Moutschen-Dahmen, M. \& Moutschen J. (1977).Genetic and cytogenetical effects of formaldehyde and related compounds. Mutat. Res., V. 39, pp. 317-362, ISSN: 0027-5107

Attwood, M. M. \& Quayle, J. R. (1984). Formaldehyde as a central intermediary metabolite of methylotrophic metabolism, In: Microbial Growth on C1 Compounds, R. L. Crawford, R. S. Hanson (Ed.), pp. 315-323, American Society for Microbiology, D.C., ISBN: 0-914826-59X, Washington

Avigad, G. (1983). A simple spectrometric determination of formaldehyde and other aldehydes: application to periodate oxidized glycerol systems. Anal. Biochem., V. 134, № 2, pp. 499-504, ISSN: 0003-2697

Azachi, M., Henis, Y. \& Oren, A. (1995). Transformation of formaldehyde by a Halomonas sp. Can. J. Microbiol., V. 41, № 6, pp. 548-553, ISSN: 1480-3275

Baerends, R.J.S., Sulter, G. J. \& Jeffries,T.W. (2002). Molecular characterization of the Hansenula polymorpha FLD1 gene encoding formaldehyde dehydrogenase. Yeast, V.19, pp. 37-42, ISSN: 0099-2240

Bakar, A.A., Salleh, A.B. \& Abdulamir, Y. H. (2009). Areview: Methods of determination of health-endangering formaldehyde in diet. Res. J. Pharmacol., V. 3, № 2, pp. 31-47, ISSN: 1815-9362

Ben Ali, M., Korpan, Y. \& Gonchar, M. (2006). Formaldehyde assay by capacitance versus voltage and impedance measurements using be-layer bio-recognition membrane. Biosens. Bioelectron., V. 22, № 5, pp. 575-581, ISSN: 0956-5663

Ben Ali, M., Gonchar, M. \& Gayda, G. (2007). Formaldehyde-sensitive sensor based on recombinant formaldehyde dehydrogenase using capacitance versus voltage measurements. Biosens. Bioelectron., V. 22, N 12, pp. 2790-2795, ISSN: 0956-5663

Benchman, I.E. (1996). Determination of formaldehyde in frozen fish with formaldehyde dehydrogenase using flow Injection system with an Incorporated gel-filtration chromatography column. Anal. Chim. Acta, V. 320, № 2-3, pp. 155-164, ISSN: 00032670

Boonamnuayvitaya, V., Sae-ung, S., \& Tanthapanichakoon, W. (2005). Preparation of activated carbons from offee residue for the adsorption of formaldehyde. Separation and Purification Technology, V.42, pp. 159-168, ISSN: 1383- 5866

Casanova, M., Deyo, D. F. \& Heck, H. D'a. (1989). Covalent Binding of Inhaled Formaldehyde to DNA in the Nasal Mucosa of Fischer 344 Rats: Analysis of Formaldehyde and DNA by High-Performance Liquid Chromatography and Provisional Pharmacokinetic Interpretation. Toxicological Sciences, V.12, Iss.3, pp. 397-417, ISSN 1096-6080

Casanova-Schmitz, M., Starr, T.B.\& Heck, H.d'A. (1984). Differentiation between metabolic incorporation and covalent binding in the labeling of macromolecules in the rat nasal mucosa and bone marrow by inhaled $\left[{ }^{14} \mathrm{C}\right]-$ and $\left[{ }^{3} \mathrm{H}\right]$ formaldehyde. Toxicol. Appl. Pharmacol., V. 76, pp. 26-44, ISSN: 0041-008X

Cazorla, A.M.D.C. \& Grutzeck, M. (2006). Indoor air pollution control: Formaldehyde adsorption by zeolite rich materials. Ceramic transactions, V. 176, pp. 3-13, ISSN: 1042-1122 
Chan, W.H. \& Xie, T.Y. (1997). Adsorption voltammetric determination of ug 1-1 levels formaldehyde via in situ derivatization with girard's reagent T. Anal. Chim. Acta, V. 339, № 1, pp. 173-179, ISSN: 0003-2670

Cox, C.H. (1994). Fabulous formaldehyde. Technicon Histology Quarterly, V. 3, pp. 4-6

Delorme, E. (1989). Transformation of Sacharomyces cerevisiae by electroporation. Appl.Environ.Microbiol., V. 55, №9, pp. 2242-2246, ISSN: 0099-2240

Demkiv, O.M., Paryzhak, S.Y. \& Krasovs'ka. (2005). Construction of methylotrophic yeast Hansenula polymorpha strains overproducing formaldehyde dehydrogenase. Biopolymers and cell, V. 21, pp. 525-530 (in Ukrainian), ISSN: 0233-7657

Demkiv, O.M., Paryzhak, S.Ya. \& Gayda, G.Z. (2007). Formaldehyde dehydrogenase from the recombinant yeast Hansenula polymorpha: isolation and bioanalytic application. FEMS Yeast Research., V. 7, pp. 1153-1159, ISSN: 1567-1356

Demkiv, O., Smutok, O. \& Paryzhak, S. (2008). Reagentless amperometric formaldehydeselective biosensors based on the recombinant yeast formaldehyde dehydrogenase. Talanta, V. 76, № 4, pp. 837-846, ISSN: 0039-9140

Demkiv, O. M., Gayda, G. Z. \& Gonchar, M. V. (2009).An enzymatic method for formaldehyde assay based on formaldehyde dehydrogenase from the recombinant yeast Hansenula polymorpha. Ukr. biochem. J., V. 81, № 6, 111-120, ISSN: 0201-8470

Dennison, M.J., Hall, J.M. \& Turner, A.P.F. (1996). Direct monitoring of formaldehyde vapour and detection of ethanol vapour using dehydrogenase-based biosensors. Analyst, V. 121, № 12, pp. 1769-1774, ISSN: 0003-2654

Dzyadevych, S.V., Arkhypova, V.N. \& Korpan, Y.I. (2001). Conductometric formaldehyde sensitive biosensor with specifically adapted analytical characteristics. Anal. Chim. Acta, V. 445, № 1, pp. 47-55, ISSN: 0003-2670

Egli, Th., Haltmeier, Th. \& Fiechter, A. (1982). Regulation of the synthesis of methanol oxidizing enzymes in Kloeckera sp. 2201 and Hansenula polymorpha, a comparison. Archives of Microbiology, V.131, № 2, pp. 174-175, ISSN: 1432-072X

Feron, V. J., Til, H. P. \& Vrijer de, F. (1991). Aldehydes: occurrence, carcinogenic potential, mechanism of action and risk assessment. Mutat. Res., V. 259, pp. 363-385, ISSN: 1383-5718

Fujii, Y., Yamasaki, Y. \& Matsemoto, M. (2004). The artificial evolution of an enzyme by random mutagenesis: The development of formaldehyde dehydrogenase. Biosci. Biotechnol. Biochem., V.68, № 8, pp. 1722-1727, ISSN: 0916-8451

Gayda, G., Demkiv, O. \& Gonchar, M. (2008). Recombinant formaldehyde dehydrogenase and gene-engineered methylotrophic yeasts as bioanalitycal instruments for assay of toxic formaldehyde. In: "Algal Toxins: Nature, Occurrence, Effect and Detection". Evangelista, V. et al. (Ed.). pp. 311-333. Series: NATO Science for Peace and Security. VIII, ISBN: 978-1-4020-8478-2.

Geier, D.A. \& Geier, M.R. (2004). Neurodevelopmental disorders following thimerosalcontaining childhood immunizations: a follow-up analysis. Int. J. Toxicol., V. 23, pp. 369-376, ISSN: 1091-5818

Gerberich, H. \& Seaman, G. (1994). Formaldehyde. In: Encyclopedia of Chemical Technology. $4^{\text {th }}$ edit. V. 11, John Wiley \& Sons (Ed.), pp. 929-951, New York, ISBN: 0-471-41961-3 
Glancer-Šoljan, M., Šoljan, V. \& Dragičević, T.L. (2001). Aerobic degradation of formaldehyde in wastewater from the production of melamine resins. Food Technol. Biotechnol., V. 39, № 3, pp. 197-202, ISSN: 1330-9862

Gonchar, M.V., Ksheminska, G.P. \& Hladarevska, N.M. (1990). Catalase-minus mutants of methylotrophic yeast Hansenula polymorpha impaired in regulation of alcohol oxidase synthesis. Proc. Intern. Conf. "Genetics of Respiratory Enzymes in Yeasts" (July 29 - August 3, 1990, Karpacz, Poland) / Ed. by T.M. Lachowicz. pp. 222-228.Wroclaw: Wroclaw University Press

Gonchar, M.V., Maidan, M.M. \& Moroz, O. M. (1998). Microbial $\mathrm{O}_{2}$-and $\mathrm{H}_{2} \mathrm{O}_{2}$-electrode sensors for alcohol assays based on the use of permeabilized mutant yeast cells as the sensitive bioelements. Biosens. Bioelectron., V.13, pp. 945-952, ISSN: 0956-5663

Gonchar, M.V., Maidan, M.M. \&, Pavlishko. (2001). A new oxidase-peroxidase kit for ethanol assays in alcoholic beverages. Food Technol. Biotechnol., V. 39, № 1, pp. 3742. ISSN: 1330-9862

Gonchar, M., Maidan, M. \&, Korpan, Y. (2002). Metabolically engineered methylotrophic yeast cells and enzymes as sensor biorecognition elements. FEMS Yeast Research., V. 2, pp. 307-314, ISSN: 1567-1356

Griesemer, R.A., Ulsamer, A.G. \& Acros, J.C. (1982). Report of the Federal panel on formaldehyde. Environ. Health Persp., V.43, pp. 137-168, ISSN: 0091-6765

Hall, E.A.H., Preuss, M. \&Gooding, J.J. (1998). Exploring Sensors to Monitor Some Environmental Discharges. In: Biosensors for Direct Monitoring of Environmental Pollutants in Field, Nikolelis, D.P., Krull, U.J.Wang, J. \& Mascini, M. (Ed.), pp: 227237, Kluwer Academic, London, ISBN 978-0-7923-4867-2.

Hämmerle, M., Hall, E.A.H. \& Cade, N. (1996). Electrochemical enzyme sensor for formaldehyde operating in the gas phase. Biosens. Bioelectron., V. 11, № 3, pp. 239246, ISSN: 0956-5663.

Harder, W.\&Veenhuis, M. (1989). Metabolism of one-carbon compounds, In: The YEASTS. Part III. 2nd ed. Rose A.H., Harrison J.S. (Eds.) Academic Press Ltd. pp. 289-316, London, New York, San Diego, ISBN: 0-12-596412-9

Hartner, F.S. \& Glider, A. (2006). Regulation of methanol utilisation pathway genes in yeasts. Microb. Cell Factories, V. 5, № 39, pp. 1-21, ISSN: 1475-2859

Heck, H.d'A \& Casanova-Schmitz, M. (1984). Biochemical toxicology of formaldehyde. Rev. Biochem. Toxicol., V. 6, pp. 155-189, ISSN: 0163-7673

Herschkovitz, Y., Eshkenazi, I. \& Campbell, C.E. (2000). An electrochemical biosensor for formaldehyde.J. Electroanal. Chem., V. 491, № 1-2, pp. 182-187, ISSN: 0022-0728

Hinnen, A., Hicks, J.B. \& Fink, G.R. (1978). Transformation of yeast. PNAS, V. 75, pp.19291933, ISSN: 0027-8424

Ito, H., Fukuda, Y. \&, Murata, K. (1983). Transformation of intact yeast cells treated with alkali cations. J. Bacteriol., V. 153, № 1, pp. 163-168, ISSN: 0021-9193

Jung, S.H., Kim, J.W. \& Jeon, I.G. (2001). Formaldehyde residues in formalin-treated olive flounder (Paralichthys olivaceus), black rockfish (Sebastes schlegeli) and seawater. Aquaculture, V.194, № 3-4, pp. 253- 262, ISSN: 0044-8486 
Kaszycki, P. \& Kołoczek, H. (2000). Formaldehyde and methanol biodegradation with the methylotrophic yeast Hansenula polymorpha in a model wastewater system. Microbiol. Res., V. 154, № 4, pp. 289-296, ISSN: 0944-5013

Kaszycki, P. \& Koloczek, H. (2002). Biodegradation of formaldehyde and its derivatives in industrial wastewater with methylotrophic yeast Hansenula polymorpha and with the yeast-bioaugmented activated sludge. Biodegradation, V. 13, №2, pp. 91-99, ISSN: 0923-9820

Kaszycki, P., Czechowska, K. \& Petryszak, P. Methylotrophic extremophilic yeast Trichosporon sp.: a soil-derived isolate with potential applications in environmental biotechnology. Acta Biochim Pol., V. 53, № 3, pp. 463-473, ISSN: 0378-1119

Kaszycki, P., Tyszka, M. \& Malec, P. (2001). Formaldehyde and methanol biodegradation with the methylotrophic yeast Hansenula polymorpha. An application to real wastewater treatment. Biodegradation, V. 12, № 3, pp. 169-177, ISSN: 0923-9820.

Kataky, R., Bryce, M.R. \& Goldenberg, L. (2002). A biosensor for monitoring formaldehyde using new lipophilic tetrathiaful valene-tetracyanoquinodimethane salt and a polyurethane membrane. Talanta, V. 56, №3, pp. 451-458, ISSN: 0039-9140.

Kato, N., Omori, G. \& Tani, Y. (1976) Alcohol oxidase of Kloeckera sp. and Hansenula polymorpha. Catalytic properties and subunit structure. Eur. J. Biochem. V. 64, pp. 341-350

Kato, N., Miyawak, N. \& Sakazawa, C. (1982). Oxidation of formaldehyde by resistant yeasts Debaryomyces vanriji and Trichosporon penicillatum. Agric. Biol. Chem., V. 46, № 3, pp. 655-661, ISSN: 1881-1280.

Kato, N., Shirakawa, K. \& Kobayashi, H. (1983). The dismutation of aldehydes by a bacterial enzyme. Agric. Biol. Chem., V. 47, № 1, pp. 39-46, ISSN: 0002-1369

Kato, N. (1990). Formaldehyde dehydrogenase from methylotrophic yeasts. Meth. Enzymol., V. 188, pp. 455-459.

Kawamura, K., Kerman, K. \& Fujihara, M. (2005). Development of a novel hand-held formaldehyde gas sensor for the rapid detection of sick building syndrome. Sens. Actuators. B. Chem., V. 105, pp. 495-501, ISSN: 0925-4005

Khlupova, M., Kuznetsov, B. \& Demkiv, O. (2007). Intact and permeabilized cellsof the yeast Hansenula polymorpha as bioselective elements for amperometric assay of formaldehyde. Talanta, V. 71, № 2, pp. 934-940, ISSN: 0039-9140

Khoder, M.I., Shakour, A.A. \& Farag, S.A. A.A. (2000). Indoor and outdoor formaldehyde concentrations in homes in residential areas in Greater Cairo. J. Environ. Monitor. V. 2, pp. 123-126, ISSN: 1464-0325

Kitchens, J.F., Casner, R..E. \& Edwards, G.S. (1976). Investigation of Selected Potential Environmental Contaminants: Formaldehyde. USEPA 560/2-76-009, pp. 22-98

Klei van der, I.J., Bystrykh, L.V. \& Harder, W. (1990). Alcohol oxidase from Hansenula polymorpha CBS 4732. Methods Enzymol., V. 188, pp. 420-427, ISSN: 0076-6879

Korpan, Y.I., Gonchar, M.V. \& Starodub, N.F. (1993). A cell biosensor specific for formaldehyde based on $\mathrm{pH}$-sensitive transistors coupled to methylotrophic yeast cells with genetically adjusted metabolism. Anal. Biochem., V. 215, № 2, 216-222, ISSN: 0003-2697. 
Korpan, Y.I., Gonchar, M.V. \& Sibirny, A.A. (1997). A novel enzyme biosensor spesific for formaldehyde based on $\mathrm{pH}$ - sensitive field effect transistors. J. Chem. Technol. Biotechnol., V. 68, pp. 209-213

Korpan, Y.I., Gonchar, M.V. \& Sibirny, A.A. (2000). Development of highly selective and stable potentiometric sensors for formaldehyde determination. Biosens. Bioelectron., V. 15, № 1-2, pp. 77-83, ISSN: 0956-5663.

Korpan,. Y.I,. Soldatkin, O.O. \& Sosovska, O. F. (2010) Formaldehyde-sensitive conductometric sensors based on commercial and recombinant formaldehyde dehydrogenase. Microchim Acta, V. 170, N 3 - 4, pp. 337 - 344

Laemmli, U.K. (1970). Cleavage of structural proteins during the assembly of the head of bacteriophage T4. Nature (London), V. 227, pp. 680-685, ISSN: 0028-0836

Lee, Y.G., Oh, C. \& Kim, D.W. (2008). Preparation of composite silica particles for the removal of formaldehyde at room temperature. J. Ceramic Processing Research ., V. 9, pp. 302-306, ISSN: 1229-9162

Li, J., Zhu, J. \& Ye, L. (2007). Determination of formaldehyde in squid by high performance liquid chromatography. Asia Pac. J. Clin. Nutr., V. 16, № 1, pp. 127-130, ISSN: 09647058.

Luong, J.H.T., Mulchandani, A. \& Guilbaul, G.G. (1988). Developments and applications of biosensors. Trends Biotechnol., V. 6, № 12, pp. 310-316, ISSN: 0167-7799.

Martin, C.N., McDermid, A.C. \& Garner, R.C. (1978). Testing of known carcinogens and noncarcinogens for their ability to induce unscheduled DNA synthesis in HeLa cells. Cancer Res., V. 38, N8, pp. 2621-2627, ISSN: 0008-5472

Melissis, S.C., Rigden, D.J. \& Clonisa, Y.D. (2001). New family of glutathionyl-biomimetic ligands for affinity chromatography of glutathione-recognising enzymes. J. of Chromatography A, V. 917, pp. 29-42, ISSN: 0021-9673

Mello, L.D. \& Kubota, L.T. (2002). Review of the use of biosensors as analytical tools in the food and drink industries. Food Chem., V. 77, № 2, pp. 237-256, ISSN: 0308-8146

Mirdamadi, S., Rajabi, A. \& Khalilzadeh, P. (2005). Isolation of bacteria able to metabolize high concentrations of formaldehyde. World J. Microbiol. Biotechnol., V. 21, № 6-7, pp. 1299-1301, ISSN: 0959-3993

Mitsui, R., Omori, M., Kitazawa, H. \& Tanaka, M. (2005). Formaldehyde-limited cultivation of a newly isolated methylotrophic bacterium, Methylobacterium sp. MF1: enzymatic analysis related to C1 metabolism. J. Bioscience Bioengineering, V. 99, № 1, 18-22, ISSN: $1389-1723$

Nash, T. (1953). The colorimetric estimation of formaldehyde by means of the Hantsch reaction. Biochem. J., V. 55, № 1, pp. 416-421, ISSN: 0264-6021

National Research Council (1982). Formaldehyde and Other Aldehydes. USEPA 600/6-82002, pp. 5-96

Ngounou, B., Neugebauer, S. \& Frodl, A. (2004). Combinatorial synthesis of a library of acrylic acid-based polymers and their evaluation as immobilisation matrix for amperometric biosensors. Electrochim. Acta, V. 49, pp. 3855-3863, ISSN: 0013-4686

Nikitina, O., Shleev, S. \& Gayda, G. (2007). Bi-enzyme biosensor based on NAD ${ }^{+}$and glutathione-dependent recombinant formaldehyde dehydrogenase and diaphorase for formaldehyde assay. Sens. Actuat. B Chem., V. 125, № 1, pp. 1-9, ISSN: 0925-4005 
Offit, P. \& Jew, R. (2007). Addressing parents' concerns: do vaccines contain harmful preservatives, adjuvants, additives, or residuals. Pediatrics, V. 112, № 6, pp. 13941401, ISSN: 0031-4005

Oliveira, S.V.W.B., Moraes, E.M. \& Adorno, M.A.T. (2004). Formaldehyde degradation in an anaerobic packed-bed bioreactor. Water Research, V. 38, № 7, pp. 1685 1694, ISSN: 0043-1354.

Otson, R. \& Fellin, P. (1992). Volatile organics in the indoor environment: sources and occurrence. In: Nriagu J.O. (Ed.). Gaseous Pollutants: Characterization and Cycling, John Wiley and Sons, Inc., New York, 335-421, ISBN: 978-0-471-54898-0

Paryzhak, S., Demkiv, O. \& Gayda, G. (2007). Enzyme- and cells-based biosensors for assay of formaldehyde in vaccines. Proc. 2nd Polish-Ukrainian Weigl Conference "Microbiology in the XXI century", Warsaw Agricultural University-SGGW, pp.170173, September 2007, Poland

Paryzhak, S., Demkiv, O. \& Schuhmann, W. (2008). Intact recombinant cells of the yeast Hansenula polymorpha, over-producing formaldehyde dehydrogenase, as the sensitive bioelements for amperometric assay of formaldehyde. Sensor Electronics and Microsystems Technologies, V. 2, pp. 28-38.

Patel, R. N., Hou, C. T. \& Derelanko, P. (1983). Microbial oxidation of methanol: Purification and properties of formaldehyde dehydrogenase from a Pichia sp. NRRL-Y-11328. Archives of Biochemistry and Biophysics, V. 221, Is. 1, pp. 135-142

Pavlishko, H.M., Honchar, T.M. \& Gonchar, M.V. (2003). Chemical and enzymatic assay of formaldehyde content in fish food. Experiment Clin Physiol Biochem., V. 4, pp. 56-63 (in Ukrainian), ISSN: 1609-6371

Pilat, P. \& Prokop, A. (1976). Oxidation of methanol, formaldehyde and formic acid by methanol-utilizing yeast. Folia Microbiol., V. 21, № 4, 306-314, ISSN: 0015-5632

Plunkett, E.R. \& Barbela, T. (1977). Are embalmer's at risk? Am. Ind. Hyg. Assoc. J., V. 38, N 1, pp. 61-62, ISSN: 0002-8894

Polish standard PN-71/c-04593. (1988). Water and sewage. Determination of formaldehyde. pp. 13. Polish Committee Standardization, Warsaw

Pourmotabbed, T. \& Creighton, D.J. (1986). Substrate specificity of bovine liver formaldehyde Dehydrogenase. J. Biol. Chem., V. 261, pp. 240-244, ISSN: 0021-9258

Prado, O.J., Veiga, M.C. \& Kennes, C. (2004). Biofiltration of waste gases containing a mixture of formaldehyde and methanol. Applied microbiology and biotechnology, V. 65, pp. 235-242, ISSN: 0175-7598

Prado, O.J., Veiga, M.C. \& Kennes, C. (2006). Effect of key parameters on the removal of formaldehyde and methanol in gas-phase biotrickling filters. Hazardous materials .J. V. 138, pp. 543-548, ISSN: 0304-389

Rehbein, H. (1995). Formaldehyd und Dimethylamin in tiefgekuhlten Fischerzeugnissen aus dem Handeleine Bestandsaufnahme. Archiv Lebensmittelhyg., V. 46, pp. 122-124, ISSN: 0003-925X

Rindt, K.P. \& Scholtissek, S. (1989). An Optical Biosensor for the Determination of Formaldehyde. In: Biosensors: Application in Medicine, Environmental Protection and Process Control, GBF Monographs, Schmid, R.D. \& Scheller, F.W., (Ed.), pp: 405-415, Wiley, VCH, Weinheim, ISBN 0895739550 (U.S.) 3527280324 (Germany) 
Sakaguchi, K., Kurane, R. \& Murata, M. (1975). Assimilation of Formaldehyde and Other $\mathrm{C}_{1}$-Compounds by Gliocladium deliquescens and Paecilomyces varioti. Agric. Biol. Chem., V. 39, № 9, pp. 1695-1702, ISSN: 1881- 1280

Sawicki, E., Hauser, T.R. \& Stanley, T.W. (1961). Sensitive new methods for the detection, rapid estimation and determination of aliphatic aldehydes. Anal Chem., V.33, 93-96, ISSN: 2700-0003

Sawicki, E., Hauser, T.R. \& McPherson, S. (1962). Spectrophotometric determination of formaldehyde and formaldehyde-releasing compounds with chromotropic acid, 6amino-1-naphtol-3-sulfonic-acid (J acid), and anilino-1-naphtol-3-sulfonic acid (phenyl. acid). Anal. Chem., V. 34, № 11, pp. 1460-1464, ISSN: 0003- 2700.

Schechter, D.S. \& Singer, P.C. (1995). Formation of aldehydes during ozonation. Ozone Sci Eng., V. 17, pp. 53-55, ISSN: 0191-9512

Schütte, H., Flossdorf, J., Sahm, H. \& Kula, M.R. (1976). Purification and properties of formaldehyde dehydrogenase and formate dehydrogenase from Candida boidinii. Eur. J. Biochem., V. 62, № 1, pp. 151-160, ISSN: 0014-2956.

Sekine, Y. (2002). Oxidative decomposition of formaldehyde by metal oxides at room temperature. Atmospheric Environment., V. 36, pp. 5543-5547, ISSN: 2310-1352

Shaham, J., Bomstein, Y. \& Meltzer, A. (1996). DNA-protein crosslinks, a biomarker of exposure to formaldehyde in vitro and in vivo studies. Carcinogenesis, V.17, pp. 121-125, ISSN: 3334-0143

Shkotova, L.V., Soldatkin, A.P. \& Gonchar, M.V. (2006). Amperometric biosensor for ethanol detection based on alcohol oxidase immobilised within electrochemically deposited Resydrol film. Materials Sci. Engineering C, V. 26, pp. 411-414, ISSN: 09284931

Shleev, S. V., Shumakovich, G.P. \& Nikitina, O.V. (2006). Purification and characterization of alcohol oxidase from the genetically constructed over-producing strain of the methylotrophic yeast Hansenula polymorpha. Biochemistry (Moscow), V. 71, № 3, pp. 245-250, ISSN: 0006-2979

Sibirnyi, V.A., Gonchar, M.V. \& Riabova, O.B. (2005). Modern methods for formaldehyde, methanol and ethanol analysis. Mikrobiol Z. (Kiev), V. 67, №. 4, pp. 85-110, ISSN: 1028-0987.

Sibirny, V.A., Gonchar, M.V. \& Grabek-Lejko, D. (2008). Photometric assay of methanol and formaldehyde in industrial waste-waters using alcohol oxidase and 3-methyl-2benzothiazolinone hydrazone. Intern. J. Environ. Anal. Chem., V. 88, № 4, pp. 289301, ISSN: 0306-7319

Sigawi, S., Smutok, O. \& Gayda, G. (2010). Enzyme and yeast-cell based bioreactors for formaldehyde removal from air, The $46^{\text {th }}$ Conference of IIChE, p. 39, Haifa, Israel

Smutok, O., Ngounou, B. \&, Pavlishko, H. (2006). A reagentless bienzyme amperometric biosensor based on alcohol oxidase/peroxidase and an Os-complex modified electrodeposition paint. Sensors Actuators B: Chem., V. 113, № 2, pp. 590-598, ISSN: 0925-4005

Takano,T., Murakami, T. \& Kamitakahara, H. (2008). Formaldehyde adsorption by karamatsu (Larix leptolepis) bark. . Wood Science, V.54, pp. 332-336, ISSN: 14350211 
Tanaka, N., Kusakabe, T. \& Ito, K. (2003). Crystal structure of glutathione-independent formaldehyde dehydrogenase. Chemico-Biol. Interact., V. 143-144, № 1, pp. 211-218, ISSN: 0009-2797

Tian, H. \& He, J. (2009). An advance in complete oxidation of formaldehyde at low temperatures. Science Foundation in China, V.17, pp. 36-38, ISSN: 1005-0841

Tseng, C.H., Hsieh, C.D. \& Chen, S.S. (2005). The Removal of Indoor Formaldehyde by Various Air Cleaners. Air and Waste Management Association's 98th Annual Conference, p. 457, Minneapolis, Minnesota.

United States Patent 6242244. Microbial system for formaldehyde sensing and remediation.

Uotila, L. \& Mannervik, B. (1979). A steady-state kinetic model for formaldehyde dehydrogenase from human liver. Biochem. J., V. 177, pp. 869-878, ISSN:-0264 6021

Van Dijk, R., Faber, K.N. \& Kiel, J.A.K.W. I. (2000). The methylotrophic yeast Hansenula polymorpha: A versatile cell factory. Enzyme Microbial Technol., V. 26, № 9-10, pp. 793-800, ISSN: 0141-0229

Van Dijken, J. P., Veenhuis, M. \& Kreger-VanRij, N. Y. W. (1975). Microbodies in methanolassimilating yeasts. Arch. Microbiol., V. 102, №1, pp. 41-44, ISSN: 0302-8933

Vastarella, W. \& Nicastri, R. (2005). Enzyme/semiconductor nanoclusters combined systems for novel amperometric biosensors. Talanta, V. 66, pp. 627-633, ISSN: 00399140

Vianello, F., Stefani, A. \& Di Paolo, M.L. (1996). Potentiometric detection of formaldehyde in air by an aldehyde dehydrogenase FET. Sens. Actuat. B Chem., V. 37, № 1-2, pp. 4954, ISSN: 0925-4005

Vianello, F., Boscolo-Chio, R. \& Signorini, S. (2007). On-line detection of atmospheric formaldehyde by a conductometric biosensor. Biosens. Bioelectrons, V. 22, № 6, pp. 920-925, ISSN: 0956-5663

Vidal, G., Jiang, Z. P., Omil, F., Thalasso, F., Méndez, R. \& Lema, J. M. (1999). Continuous anaerobic treatment of wastewaters containing formaldehyde and urea. Bioresour. Technol., V. 70, № 3, 283-291, ISSN: 0960-8524

Walker, J.F. (1964). Formaldehyde, 3rd ed, Reinhold, pp. 483-510, New York

Winter, B. \& Cammann, K. (1989). Formaldehyde analysis by electrochemical biosensor-FIA. Fresenius Zeitschrift FurAnalytische Chemie, V. 334, № 7, pp. 720-721, ISSN: 0016-1152

Woodward, J. (1990). Biochemistry and applications of alcohol oxidase from methylotrophic yeasts. Autotrophic microbiology and one-carbon metabolism. Dordrech: Kluwer Acad. Publ., pp. 193-225.

Xu, Z., Qin, N. \& Wang, J. (2010). Formaldehyde biofiltration as affected by spider plant. Bioresour. Technol., V. 101, № 18, pp. 6930-6934, ISSN: 0960-8524

Yocom, Y.E. \& McCarthy, S.M. (1991). Measuring Indoor Air Quality. A Practical Guide, Wiley, Chichester

Yoshida, K., Ishii, H. \& Ishihara, Y. (2009). Bioremediation potential of formaldehyde by the marine microalga Nannochloropsis oculata ST-3 Strain. Applied Biochem. Biotechnol., V. 157, № 2, pp. 321-328, ISSN: 0273-2289 
Yurimoto, H., Kato, N. \& Sakai, Y. (2005). Assimilation, dissimilation, and detoxification of formaldehyde, a central metabolic intermediate of methylotrophic metabolism. Chem. Rec., V. 5, № 6, pp.367-375, ISSN: 1527-8999

Zhang, Q., Xie, C. \& Zhang, S. (2005). Identification and pattern recognition analysis of Chinese liquors by doped nano $\mathrm{ZnO}$ gas sensor array. Sens. Actuat. B Chem., V. 110, № 2, pp. 370-376, ISSN: 0925-4005 


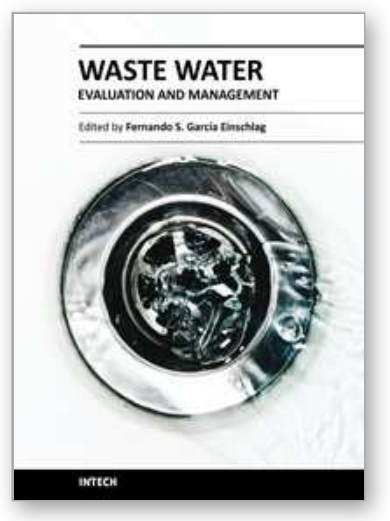

\author{
Waste Water - Evaluation and Management \\ Edited by Prof. Fernando Sebastĩ̃̃in GarcÃa Einschlag
}

ISBN 978-953-307-233-3

Hard cover, 470 pages

Publisher InTech

Published online 01, April, 2011

Published in print edition April, 2011

Fresh water resources are under serious stress throughout the globe. Water supply and water quality degradation are global concerns. Many natural water bodies receive a varied range of waste water from point and/or non point sources. Hence, there is an increasing need for better tools to asses the effects of pollution sources and prevent the contamination of aquatic ecosystems. The book covers a wide spectrum of issues related to waste water monitoring, the evaluation of waste water effect on different natural environments and the management of water resources.

\title{
How to reference
}

In order to correctly reference this scholarly work, feel free to copy and paste the following:

Vladimir Sibirny, Olha Demkiv, Sasi Sigawi, Solomiya Paryzhak, Halyna Klepach, Yaroslav Korpan, Oleh Smutok, Marina Nisnevich, Galina Gayda, Yeshayahu Nitzan, Czesław Puchalski and Mykhailo Gonchar (2011). Formaldehyde Oxidizing Enzymes and Genetically Modified Yeast Hansenula polymorpha Cells in Monitoring and Removal of Formaldehyde, Waste Water - Evaluation and Management, Prof. Fernando Sebastî̃ in GarcÃa Einschlag (Ed.), ISBN: 978-953-307-233-3, InTech, Available from:

http://www.intechopen.com/books/waste-water-evaluation-and-management/formaldehyde-oxidizing-enzymesand-genetically-modified-yeast-hansenula-polymorpha-cells-in-monitori

\section{INTECH}

open science | open minds

\author{
InTech Europe \\ University Campus STeP Ri \\ Slavka Krautzeka 83/A \\ 51000 Rijeka, Croatia \\ Phone: +385 (51) 770447 \\ Fax: +385 (51) 686166 \\ www.intechopen.com
}

\author{
InTech China \\ Unit 405, Office Block, Hotel Equatorial Shanghai \\ No.65, Yan An Road (West), Shanghai, 200040, China \\ 中国上海市延安西路 65 号上海国际贵都大饭店办公楼 405 单元 \\ Phone: +86-21-62489820 \\ Fax: +86-21-62489821
}


(C) 2011 The Author(s). Licensee IntechOpen. This chapter is distributed under the terms of the Creative Commons Attribution-NonCommercialShareAlike-3.0 License, which permits use, distribution and reproduction for non-commercial purposes, provided the original is properly cited and derivative works building on this content are distributed under the same license. 